\title{
Promise for plant pest control: root-associated pseudomonads with insecticidal activities
}

\author{
Peter Kupferschmied ${ }^{1}$, Monika Maurhofer ${ }^{2}$ and Christoph Keel ${ }^{1}$ * \\ 1 Department of Fundamental Microbiology, University of Lausanne, Lausanne, Switzerland \\ 2 Plant Pathology, Institute of Integrative Biology, Swiss Federal Institute of Technology Zurich, Zurich, Switzerland
}

\section{Edited by:}

Ana Pineda, Wageningen University, Netherlands

Reviewed by:

Philippe Reymond, University of Lausanne, Switzerland

Christina Nielsen-LeRoux, French National Institute for Agricultural Research, France

\section{*Correspondence:}

Christoph Keel, Department of Fundamental Microbiology, University of Lausanne, Biophore Building, CH-1015 Lausanne, Switzerland e-mail: christoph.keel@unil.ch
Insects are an important and probably the most challenging pest to control in agriculture, in particular when they feed on belowground parts of plants. The application of synthetic pesticides is problematic owing to side effects on the environment, concerns for public health and the rapid development of resistance. Entomopathogenic bacteria, notably Bacillus thuringiensis and Photorhabdus/Xenorhabdus species, are promising alternatives to chemical insecticides, for they are able to efficiently kill insects and are considered to be environmentally sound and harmless to mammals. However, they have the handicap of showing limited environmental persistence or of depending on a nematode vector for insect infection. Intriguingly, certain strains of plant root-colonizing Pseudomonas bacteria display insect pathogenicity and thus could be formulated to extend the present range of bioinsecticides for protection of plants against root-feeding insects. These entomopathogenic pseudomonads belong to a group of plant-beneficial rhizobacteria that have the remarkable ability to suppress soil-borne plant pathogens, promote plant growth, and induce systemic plant defenses. Here we review for the first time the current knowledge about the occurrence and the molecular basis of insecticidal activity in pseudomonads with an emphasis on plant-beneficial and prominent pathogenic species. We discuss how this fascinating Pseudomonas trait may be exploited for novel root-based approaches to insect control in an integrated pest management framework.

Keywords: Pseudomonas, insecticidal, plant-associated, entomopathogens, toxins, biocontrol, rhizosphere, Bacillus

\section{INTRODUCTION}

With the world population still experiencing continuous growth, an immediate priority of agriculture is to increase crop production to assure food security while becoming more sustainable (Gatehouse et al., 2011). One way to do so is by improving the management of pests. Weeds, plant pathogens, and certain animal species are considered to be the major pests of economic significance and together they are estimated to reduce the world's annual crop yield by approximately 30-40\% (Oerke, 2006). Due to their incredible diversity and adaptability, insects are probably the single most challenging pest to control in agriculture worldwide. Insects do not only cause major damage to agricultural crops as pests, but are also vectors of diseases. Since the introduction of synthetic insecticides, their application has made a major contribution to improve food production, but it was also soon discovered to be problematic in many ways. The rapid appearance of resistance to insecticides is a major concern in pest management. Today insect pest species of economic importance as pests that are resistant to more than 30 different chemical insecticides are no longer a rarity (Arthropod Pesticide Resistance Database, Michigan State University). Moreover, chemical insecticides are troublesome because of their potentially nocuous effects on the environment and public health (Heckel, 2012).

After decades of intensive pesticide application, it has become evident that there is no silver bullet solution to the control of pests in sustainable agriculture. The integration of many different, complementary approaches of chemical and biological control methods to solve the diverse and challenging problems with pests is the basic idea behind integrated pest management (IPM) programs (van den Bosch and Stern, 1962). Since its inception, IPM has become an increasingly important and popular toolbox-like approach to protect plants in agriculture against weeds, pathogens and animal pests (Oerke, 2006). Its tactics are designed to decrease the amount of chemical pesticides applied through careful forecasting or even to replace them by biological alternatives. The two main alternatives to synthetic insecticides are the exploitation of semiochemicals (like pheromones) to change the behavior of insects or the use of biological control agents (parasites, predators, and pathogens) to reduce the pest population size (Bale et al., 2008). IPM-based systems are becoming progressively more popular due to the increased public awareness of the above-mentioned problematic effects of synthetic pesticides and interest in the development of alternative approaches for plant pest control. Microbial products that are based on insecticidal microorganisms for biological pest management strategies are receiving particular attention.

Bacillus thuringiensis (Bt) is a Gram-positive, spore-forming soil bacterium and the insecticidal organism which is dominating the market for products for microbial control of insects (Bravo et al., 2011; Sanahuja et al., 2011). The reason for its success is 
the production of pore-forming $\delta$-endotoxins, namely Cry and Cyt proteins (Crickmore et al., 1998, 2013). These so-called crystal proteins are produced during sporulation and show potent and specific insecticidal activity. Once proteolytically activated, the Cry and Cyt proteins act in the midgut of insects as pore-forming toxins via binding to specific receptors or directly to membrane lipids, respectively (Bravo et al., 2007; Vachon et al., 2012). In addition to the well-known crystal toxins, Bt produces an array of additional virulence factors that contribute to the insecticidal activity of this bacterium (Nielsen-LeRoux et al., 2012). Bt is typically applied as topical sprays and has several advantages over conventional chemical insecticides. The bacterium's pathogenic activity is specific toward a narrow range of insect species and its application is considered to be environmentally sound and harmless to humans and other mammals. However, the use of $\mathrm{Bt}$ as a biological control agent has some limitations. The bacterium shows low environmental persistence after topical application, mainly because it is sensitive to solar irradiation as well as to the chemical environment on plant leaves, and is not a competitive plant colonizer (Bizzarri and Bishop, 2008; Raymond et al., 2010). Therefore, and because the susceptible stages of the pest insects are during the early instar larvae, Bt provides only short-term crop protection in the field and requires precise application practices (Bravo et al., 2011). The recent discovery that at least some Bt strains are capable of colonizing crop plants as endophytes and as such translocate throughout the plant (Monnerat et al., 2009) may open up an avenue for new Bt application strategies.

To overcome the problem of the low persistence of $\mathrm{Bt}$ on plants, genetically modified (GM) crops that express variants of the Cry toxins have been developed and successfully commercialized. Planting of GM crops reduced the amount of pesticides applied by $8.9 \%$ in the period from 1996 to 2011 (James, 2012) and is a component of IPM strategies due to its compatibility with biological control methods (Bale et al., 2008). However, the major drawback of this new biotechnology has been the development of resistance against the Cry toxins by pests (Bravo et al., 2011). Due to the relatively simple mode of action of Cry toxins and the absence of complementary virulence factors normally found in the complete microorganism, resistance is much more probable to develop toward the insect toxin in the GM plants than to the entire microorganism (Cory and Franklin, 2012). Infections by microbial pathogens are complex and likely to require more diverse polygenic resistance mechanisms in pest insects. In addition, there are public concerns about transgenic crops regarding their impact on biodiversity and the consumer's health and the possible dependency of farmers on seed companies. Especially in Europe, the public acceptance for GM crops is currently fairly low for these reasons.

Belowground pest insects are especially difficult to control, because they are hidden in the soil and therefore hard to detect and to get access to. Although root herbivory can cause significant damage to crops, even leading to a sudden collapse of the plant population, there is still a considerable lack of research data about root feeders and their impact on plants (Hunter, 2001; Blossey and Hunt-Joshi, 2003). For instance, the Western corn rootworm Diabrotica virgifera is a significant economic pest insect of maize in the United States and in Europe and acquired the nickname "billion dollar bug," not without reason (Gray et al., 2009). Even if this troublesome insect species has been the subject of many scientific studies, this root feeder remains challenging to control because of its cryptic lifestyle, the adaptation to crop rotation, and the development of resistance to certain insecticides. While the use of chemical pesticides for pest management in soils is extremely restricted, microbial control is a promising approach to address problems with soil-dwelling insects due to the more favorable environmental conditions for microbes in contrast to aboveground habitats (e.g., absence of ultraviolet radiation and lower risk of desiccation in the soil). Species of Photorhabdus and Xenorhabdus, bacteria which are living in symbiosis with entomopathogenic nematodes, are used in agriculture as soil-applied insecticides (Lacey and Georgis, 2012). However, contrarily to Bt, they currently only play a minor role on the market for microbial insecticides. Commercial products for pest control are based on formulations of entomopathogenic nematodes of the genera Heterorhabditis and Steinernema with select strains of Photorhabdus and Xenorhabdus (Ehlers, 2001). Preparations of Heterorhabditis and Steinernema vectoring the entomopathogenic bacteria have been applied with varying success to control larval forms of some of the most notorious soil pest insects, including the black cutworm Agrotis ipsilon of the order Lepidoptera, Diabrotica spp. and Diaprepes sp. and Otiorhynchus sp. root weevils of the Coleoptera, and the cabbage root fly Delia radicum and fungus gnats (Sciaridae) of the Diptera (Denno et al., 2008; Lacey and Shapiro-Ilan, 2008; Degenhardt et al., 2009; Toepfer et al., 2010; Campos-Herrera et al., 2012 ). The two nematodes have also been used in combination with the entomopathogenic fungus Metarhizium and Bt maize to improve root protection from damage caused by Diabrotica spp. (Petzold-Maxwell et al., 2013).

Photorhabdus and Xenorhabdus are fascinating entomopathogenic bacteria and they have been studied extensively for their insect pathogenicity and mutualistic interaction with nematodes, as well as for their production of an array of protein toxins and toxic secondary metabolites with insecticidal potential (ffrenchConstant et al., 2007; Herbert and Goodrich-Blair, 2007; Bode, 2009; Waterfield et al., 2009; Nielsen-LeRoux et al., 2012). They provide a rich source of novel insecticidal toxins for crop protection, as it will be exemplified later in this review. There have been efforts to isolate new strains of these entomopathogens to mine for novel antimicrobial and insecticidal compounds (Thanwisai et al., 2012), and to create insect-resistant plants using toxins from Photorhabdus luminescens (Liu et al., 2003). In contrast to Bt, which relies on the oral route of infection in order to kill the insect host, Photorhabdus and Xenorhabdus species are "delivered" directly into the insect hemocoel by their nematode vectors, which then invade the insects either via penetration of the cuticle or through natural openings. As a result, this infection strategy makes the bacteria dependent on their nematode symbiont, which in turn makes applications of these microorganisms for insect pest management in the soil much more complex than it would be in the case of a free-living, entomopathogenic rhizobacterium.

In this review, we present the very first detailed overview about insect interaction and insecticidal activity in pseudomonads, and we illustrate that certain root-associated bacteria of the genus Pseudomonas could constitute a promising alternative to the above- 
mentioned two groups of commercialized entomopathogens, in particular when addressing the notorious problem of soil-dwelling pests. As described in more detail below, these well-known rhizobacteria are capable of protecting plant roots against fungal and oomycete pathogens and simultaneously show potent oral insecticidal activity (Figure 1A). Some of these bacterial strains are already successfully used as antifungal biocontrol agents in agriculture (Berg, 2009). Therefore, these root-associated bacteria could be exploited for the development of novel microbial products which would protect plant roots simultaneously against phytopathogens and herbivorous insects and could become an important element of IPM.

\section{INTERACTION OF BENEFICIAL PSEUDOMONADS WITH PLANTS AND PHYTOPATHOGENS: COOPERATION, COMPETITION, AND ANTAGONISM}

The genus Pseudomonas makes up a remarkably ubiquitous and diverse group of microorganisms. These Gram-negative bacteria are highly adaptive and can use a wide variety of compounds as an energy source, and as a result, there is practically no place on earth where they cannot be found (Wu et al., 2010; Silby et al., 2011). The environmental niches that they colonize range from oil-spilled seawater (Viggor et al., 2013) to soil (Weller et al., 2002), plant surfaces (Hirano and Upper, 2000; Loper et al., 2012), and insect guts (Vodovar et al., 2005). Some of them live a life as saprophytes, while some are plant pathogens or opportunistic human pathogens, and yet others entertain commensal or almost mutualistic relationships with plants. The latter are in most cases root-colonizing members of the Pseudomonas fluorescens group according to Mulet et al. (2010, 2012b), and include amongst others the species Pseudomonas fluorescens, Pseudomonas protegens, and Pseudomonas chlororaphis. Among them, plant-beneficial pseudomonads are well-known for their multiple skills that enable them to not only survive and compete in the rhizosphere, which is an ecological hot spot attracting many different kinds of organisms, but also to undergo intimate interactions with the plant itself (Figure 1A; Lugtenberg and Kamilova, 2009; Hol et al., 2013). To this effect, the root-colonizing pseudomonads first became renowned thanks to the ability of some strains to protect plants against the attack by some of the most notorious soil-borne fungal and oomycete pathogens, including Gaeumannomyces, Thielaviopsis, Rhizoctonia, Fusarium oxysporum, and Pythium sp. (Table 1; Cook et al., 1995; Haas and Défago, 2005; Mercado-Blanco and Bakker, 2007).

The mechanisms by which pseudomonads suppress plant diseases have been studied for many years. These bacteria are excellent root colonizers and compete effectively with pathogens for rhizosphere niches and macro- and micronutrients (MercadoBlanco and Bakker, 2007; Lugtenberg and Kamilova, 2009). Notably, pseudomonads produce high affinity iron chelators (so-called siderophores such as pyoverdines and pyochelins) by which they sequester iron, which is in limited supply in soil, and render it unavailable for the pathogens (Table 1; Keel etal., 1989; Loper and Buyer, 1991; Cornelis, 2010; Youard etal., 2011). Probably the most potent mechanism by which pseudomonads can suppress soil-borne pathogens is antibiosis (Haas and Keel, 2003). Many disease-suppressive strains produce one, two, or even an entire cocktail of secondary metabolites

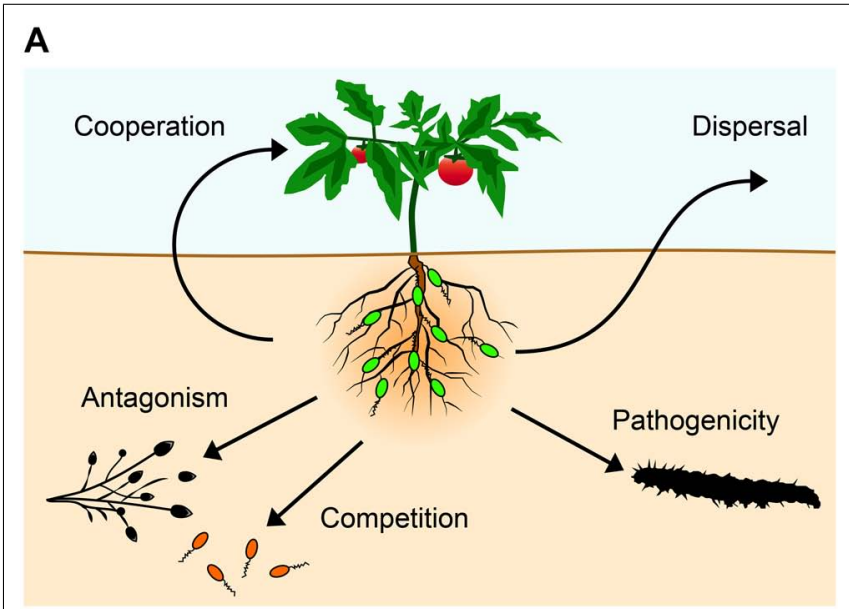

B

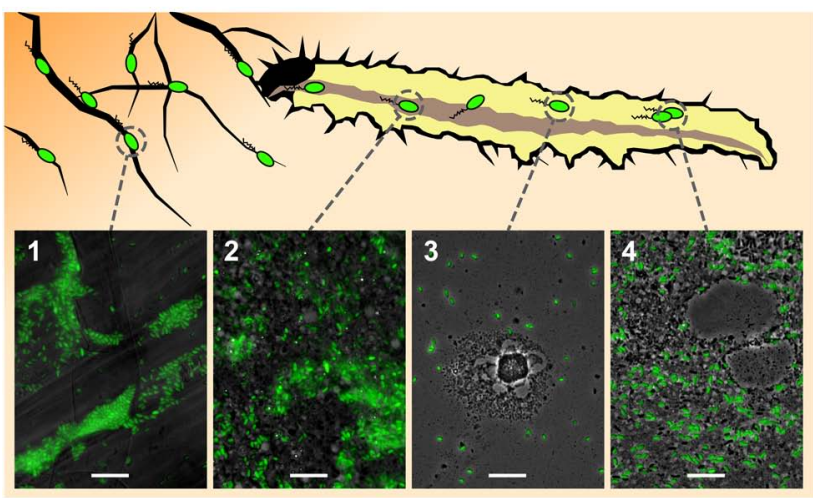

FIGURE 1 | Certain plant root-associated Pseudomonas bacteria exhibit insect pathogenicity as an additional trait to the well-studied biocontrol activity against phytopathogens (see text for more details). (A) The most important interactions of these plant-beneficial pseudomonads (in green) include cooperation with the plant host (growth promotion and induction of systemic resistance) and competition with and antagonism of soil-borne phytopathogens. In addition, they show insecticidal activity and can use insects as vectors for dispersal. (B) Certain strains of Pseudomonas protegens and Pseudomonas chlororaphis are capable of infecting and efficiently killing insect larvae after oral uptake. P. protegens strain CHAO (here tagged with GFP for microscopical visualization) typically forms microcolonies on roots (1) of various plant species (here tomato). Following ingestion by herbivorous insects, the entomopathogenic $P$. protegens strain is able to colonize the midgut (2) of pest insect larvae (here the large cabbage white Pieris brassicae), possibly by competing with the intestinal microbiota. By a so far unknown mechanism $\mathrm{CHAO}$ cells then cross the intestinal epithelial barrier and invade the hemocoel within less than 1 day after oral infection (3). Once in this body compartment, the bacteria proliferate, resist uptake and elimination by hemocytes and cause disease (4). Bars represent $10 \mu \mathrm{m}$.

with potent antifungal activity by which they can ward off plant pathogens. Phenazines, 2,4-diacetylphloroglucinol (DAPG), pyoluteorin, pyrrolnitrin, hydrogen cyanide $(\mathrm{HCN})$, and cyclic lipopeptides are metabolites with a documented role in disease suppression (Table 1; Haas and Keel, 2003; de Werra et al., 2008; Gross and Loper, 2009; Mentel et al., 2009; Raaijmakers et al., 2010; Rochat et al., 2010; Jousset et al., 2011). The pseudomonads use several of these compounds also for self-defense against 
Table 1 | Prominent root-associated Pseudomonas fluorescens group strains with biocontrol activity against plant diseases and effectors contributing to pathogen suppression.

\begin{tabular}{|c|c|c|c|c|}
\hline Strain $^{a}$ & $\begin{array}{l}\text { Target soil-borne // leaf } \\
\text { pathogens }^{\text {b }}\end{array}$ & $\begin{array}{l}\text { Pathogen suppression } \\
\text { mechanisms }^{c}\end{array}$ & $\begin{array}{l}\text { Effectors } \\
\text { (antibiotics/biosurfactants // }^{\text {siderophores) }}\end{array}$ & Reference $^{\mathrm{e}}$ \\
\hline \multicolumn{5}{|c|}{ Pseudomonas protegens } \\
\hline $\mathrm{CHAO}$ & $\begin{array}{l}\text { Thielaviopsis, Pythium, } \\
\text { Gaeumannomyces, Rhizoctonia, } \\
\text { Fusarium // Hyaloperonospora, } \\
\text { TNV }\end{array}$ & Antibiosis, ISR & $\begin{array}{l}\text { DAPG, pyrrolnitrin, pyoluteorin, } \\
\text { HCN/orfamide // pyoverdine, } \\
\text { enantiopyochelin }\end{array}$ & $\begin{array}{l}\text { Haas and Keel (2003), Haas and } \\
\text { Défago (2005), Youard etal. (2011) }\end{array}$ \\
\hline Pf-5 & $\begin{array}{l}\text { Pythium, Rhizoctonia, } \\
\text { Drechslera, Sclerotinia // Pst }\end{array}$ & Antibiosis, ISR & $\begin{array}{l}\text { DAPG, pyrrolnitrin, pyoluteorin, } \\
\text { HCN, rhizoxins/orfamide // } \\
\text { pyoverdine, enantiopyochelin }\end{array}$ & $\begin{array}{l}\text { Gross and Loper (2009); Loper et al. } \\
\text { (2012), Weller et al. (2012) }\end{array}$ \\
\hline \multicolumn{5}{|c|}{ Pseudomonas chlororaphis } \\
\hline $30-84$ & Gaeumannomyces & Antibiosis & $\begin{array}{l}\text { Phenazines, pyrrolnitrin, } \mathrm{HCN} / / \\
\text { pyoverdine }\end{array}$ & $\begin{array}{l}\text { Pierson and Pierson (2010); Loper } \\
\text { etal. (2012) }\end{array}$ \\
\hline O6 & $\begin{array}{l}\text { // Phytophthora, Corynespora, } \\
\text { Pectobacterium }\end{array}$ & Antibiosis, ISR & $\begin{array}{l}\text { Phenazines, pyrrolnitrin, } \mathrm{HCN} / / \\
\text { pyoverdine }\end{array}$ & $\begin{array}{l}\text { De Vleesschauer and Höfte (2009); } \\
\text { Park etal. (2011), Loper etal. (2012) }\end{array}$ \\
\hline PCL1391 & Fusarium & Antibiosis & Phenazines, $\mathrm{HCN} / /$ pyoverdine & $\begin{array}{l}\text { Chin-A-Woeng etal. (2001); Ruffner } \\
\text { (2013) }\end{array}$ \\
\hline \multicolumn{5}{|c|}{ Pseudomonas fluorescens } \\
\hline $2-79$ & Gaeumannomyces & Antibiosis & Phenazine // pyoverdine & Weller (2007); Mavrodi etal. (2010) \\
\hline DR54 & Pythium, Rhizoctonia & Antibiosis & Niscosinamide // pyoverdine & Nielsen and Sørensen (2003) \\
\hline F113 & $\begin{array}{l}\text { Pythium, Fusarium, } \\
\text { Pectobacterium }\end{array}$ & Antibiosis & DAPG, HCN // pyoverdine & Redondo-Nieto et al. (2013) \\
\hline Pf29A & Gaeumannomyces & $\begin{array}{l}\text { Alteration of fungal } \\
\text { pathogenesis }\end{array}$ & ND & Daval etal. (2011); Marchi etal. (2013) \\
\hline Q2-87 & Gaeumannomyces // Pst & Antibiosis, ISR & DAPG, HCN // pyoverdine & Loper etal. (2012); Weller etal. (2012) \\
\hline SBW25 & Pythium & ND & Niscosin // pyoverdine & Loper etal. (2012); Trippe etal. (2013) \\
\hline SS101 & Pythium // Phytophthora, Pst & ISR & /Massetolide // pyoverdine & $\begin{array}{l}\text { Loper etal. (2012); van de Mortel } \\
\text { etal. (2012) }\end{array}$ \\
\hline WCS374 & Fusarium // Magnaporthe, Pst & ISR & // Pyoverdine, pseudomonine & $\begin{array}{l}\text { Bakker et al. (2007); De Vleesschauer } \\
\text { and Höfte (2009) }\end{array}$ \\
\hline WCS417 & $\begin{array}{l}\text { Fusarium // Alternaria, } \\
\text { Hyaloperonospora, Botrytis, Pst }\end{array}$ & ISR & ND & $\begin{array}{l}\text { Bakker etal. (2007); Van der Ent et al. } \\
\text { (2008) }\end{array}$ \\
\hline
\end{tabular}

a Strains belonging to the P. fluorescens group according to Mulet et al. (2010, 2012b).

b Pst, Pseudomonas syringae pv. tomato; TNV, tobacco necrosis virus.

$c / S R$, induced systemic resistance. ND, not determined.

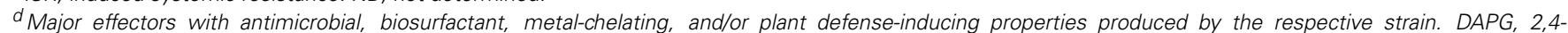
diacetylphloroglucinol; HCN, hydrogen cyanide.

${ }^{e}$ References from which further information on the strains can be accessed.

predatory protozoa and nematodes (Bjørnlund et al., 2009; Jousset et al., 2009; Raaijmakers and Mazzola, 2012). Most remarkably, root-inhabiting pseudomonads producing DAPG, phenazines, or cyclic lipopeptides are key components of soils that are naturally suppressive to specific soil-borne diseases such as take-all of wheat, black root of tobacco, and Rhizoctonia root rot of sugar beet (Weller et al., 2002; Haas and Défago, 2005; Mazurier et al., 2009; Mendes et al., 2011; Almario et al., 2013).

Several root-associated Pseudomonas strains are able to reduce plant diseases not only by directly antagonizing pathogens but also indirectly by activating plant defenses (Table $\mathbf{1}$ ). The beneficial effects of induced systemic resistance (ISR) triggered by rootcolonizing pseudomonads in mono- and dicotyledonous plants against plant pests caused by fungal, oomycete, bacterial and viral pathogens, and also by herbivorous insects are extensively documented (Maurhofer et al., 1994; Bakker et al., 2007; De Vleesschauer and Höfte, 2009; van de Mortel et al., 2012; Zamioudis and Pieterse, 2012; Balmer et al., 2013). Nevertheless, pseudomonads sometimes can also negatively interfere with plant defenses against insects or with the attraction of parasitoids of leaf-feeding insects 
(Pineda et al., 2012, 2013). A number of bacterial determinants eliciting ISR have been identified, including iron chelators such as pyoverdines and pyochelins, and antimicrobials such as DAPG, phenazines, and lipopeptides (Table 1; Bakker et al., 2007; De Vleesschauer and Höfte, 2009). Most pseudomonads that are capable of inducing systemic resistance do this by priming plants in a way which leads to an accelerated, mostly jasmonate-signaling dependent response upon pathogen or insect attack (Prime-APlant Group, 2006; Bakker et al., 2007; De Vleesschauer and Höfte, 2009).

There are two main strategies by which we can exploit these pseudomonads with their astonishing repertoire of plantbeneficial activities for improving crop performance and crop health. The first is to adapt cropping systems in a way that attracts the beneficial rhizobacteria, fosters their populations, and stimulates their activity (Janvier et al., 2007; Berendsen et al., 2012). This may be achieved in numerous ways, e.g., by adapting tillage or crop rotation practices, by soil amendments such as quality composts or by the use of inter- or covercrops (Mazzola, 2004; Janvier et al., 2007). The second strategy is to apply Pseudomonasbased biopesticides either as a seed treatment, soil drench, or foliar spray. Several products based on plant-beneficial pseudomonads for use in integrated biological control have been commercialized mainly for the US market, including AtEze (P. chlororaphis) with activity against Pythium, Rhizoctonia, and Fusarium root diseases of vegetables and ornamentals in greenhouses, BlightBan A506 (P. fluorescens) used against fire blight on apple and pear, and Bio-Save 10 LP/11 LP (Pseudomonas syringae) used for the control of post-harvest diseases of fruits and potato (Fravel, 2005). In several European countries, two formulations based on P. chlororaphis, i.e., Cedomon and Cerall, are sold as a seed treatment against seed-borne diseases of cereals (Mark et al., 2006) and the Pseudomonas-based product Proradix (Buddrus-Schiemann et al., 2010) was recently placed on the market for use as a potato tuber treatment against diseases caused by Rhizoctonia, Phytophthora, Streptomyces, and Erwinia. Considerations for the selection, production, delivery, field testing, and registration of Pseudomonas and other biocontrol agents for commercial purposes have been reviewed elsewhere (Walsh et al., 2001; Fravel, 2005; Mark et al., 2006; Berg, 2009; Höfte and Altier, 2010).

\section{INSECTICIDAL ACTIVITY IN PLANT-BENEFICIAL P. fluorescens GROUP BACTERIA: OCCURRENCE AND MOLECULAR BASIS}

Until very recently, insecticidal activities in the $P$. fluorescens group had only been sparsely documented (Table 2). Notably, strains of $P$. fluorescens were reported to exhibit insecticidal activity toward agricultural pest insects such as aphids (Hashimoto, 2002), phytophagous ladybird beetles (Otsu et al., 2004), and termites (Devi and Kothamasi, 2009). In the same vein, a bioformulation of a combination of two P. fluorescens strains was demonstrated to simultaneously reduce the incidence of a herbivorous insect (the rice leafroller Cnaphalocrocis medinalis) and a phytopathogenic fungus (Rhizoctonia solani) in rice under greenhouse and field conditions (Commare et al., 2002; Karthiba et al., 2010). Furthermore, a number of $P$. fluorescens strains were found to be capable of either killing the common fruit fly Drosophila melanogaster or of causing morphological defects to the widely used laboratory insect (de Lima Pimenta et al., 2003; Olcott et al., 2010). Although in some cases protein extracts (Prabakaran et al., 2002) or metabolites of $P$. fluorescens group strains, such as HCN (Devi and Kothamasi, 2009) and the lipopeptides viscosin (Hashimoto, 2002) and orfamide (Jang et al., 2013), were shown to have insecticidal properties, the molecular basis and regulation of the insecticidal activity in these bacteria remains obscure.

The genome sequencing of the root-colonizing biocontrol agent $P$. fluorescens strain Pf-5 (now called P. protegens Pf-5; Ramette etal., 2011) published by Paulsen etal. (2005) and of the closely related $P$. fluorescens strain CHA0 (recently renamed P. protegens CHA0; NCBI Database Bioproject PRJNA78307) and their analysis revealed astonishing results which opened a new door to future studies on plant-associated pseudomonads. After more than twenty years of research on the biocontrol properties of P. fluorescens group strains it came as a surprise that some of these bacteria do not only harbor numerous genes for the biosynthesis of antifungal metabolites, including DAPG, pyoluteorin, HCN, and pyrrolnitrin (see Table 1), in their genomes, but also possess a gene which codes for a protein that is similar to the potent insect toxin Mcfl of the entomopathogen P. luminescens (Péchy-Tarr et al., 2008).

Mcf1 was discovered in a screening of a P. luminescens W14 cosmid library aiming at the identification of new insecticidal proteins and metabolites in this entomopathogenic bacterium (Daborn et al., 2002). A single gene which was called makes caterpillars floppy ( $m c f)$ made the Escherichia coli cells expressing it capable of surviving within and killing larvae of the tobacco hornworm Manduca sexta upon injection into the hemocoel. When expressed heterologously in E. coli, Mcf1 was shown to cause hemocytes and midgut epithelial cells to undergo programmed cell death. The disintegration of the midgut caused by Mcf1 was proposed to contribute to the "floppy" phenotype of insects infected with $P$. luminescens, thereby giving the name to the newly discovered toxin. The pro-apoptotic action of Mcf1 was attributed to the predicted Bcl2-homology 3-like (BH3-like) domain at the N-terminus of the protein. The $\mathrm{BH} 3$ domain is a well-studied and important peptide motif of proteins making up part of the pro-apoptotic signal-transduction cascades in animal cells (Cory and Adams, 2002). Mcf1 has been shown to also trigger apoptosis in mammalian cells and the N-terminal part of the toxin containing the $\mathrm{BH} 3$-like domain was sufficient for the observed toxicity (Dowling et al., 2004). The potent insect toxin seems to hijack the apoptosis cascades of the cells of the innate immune system and thereby to contribute to the immune suppressive activity of $P$. luminescens.

An exciting feature of the $m c f 1$-related gene of $P$. fluorescens group strains Pf-5 and CHA0 is that, in contrast to $m c f 1$, it is part of an eight-gene cluster (Péchy-Tarr et al., 2008). The cluster was termed fit for P. fluorescens insecticidal toxin. The gene fitD, which codes for the actual insect toxin with a molecular weight of $327 \mathrm{kDa}$, is flanked by four genes ( fit $A B C-E$ ) predicted to encode a type I secretion system and three genes ( $f i t F G H)$ coding for regulatory proteins. The toxin gene is co-transcribed with the genes encoding the proteins for the putative secretion system, thereby suggesting that the toxin may be transported across the bacterial cell wall via this type I secretion system (Péchy-Tarr et al., 2013). 
Table 2 | Insecticidal activity in Pseudomonas species and currently known effectors and regulatory mechanisms involved in insect virulence.

\section{Bacterial strain $^{\mathrm{a}}$ Target insect}

\section{Pseudomonas protegens}

$\mathrm{CHAO}$

Galleria mellonella, Manduca Injection

sexta

Spodoptera littoralis

Heliothis virescens, Plutella

xylostella

Pf-5

G. mellonella, M. sexta

Drosophila melanogaster

F6

Myzus persicae

Injection

Injection
Odontotermes obesus

\section{Application of bacteria} / bacterial product ${ }^{b}$

Feeding $(D, L)$

Feeding (L)

Contact (live cells)

Feeding (D)

Contact (purified

metabolite)

\section{Pseudomonas chlororaphis}

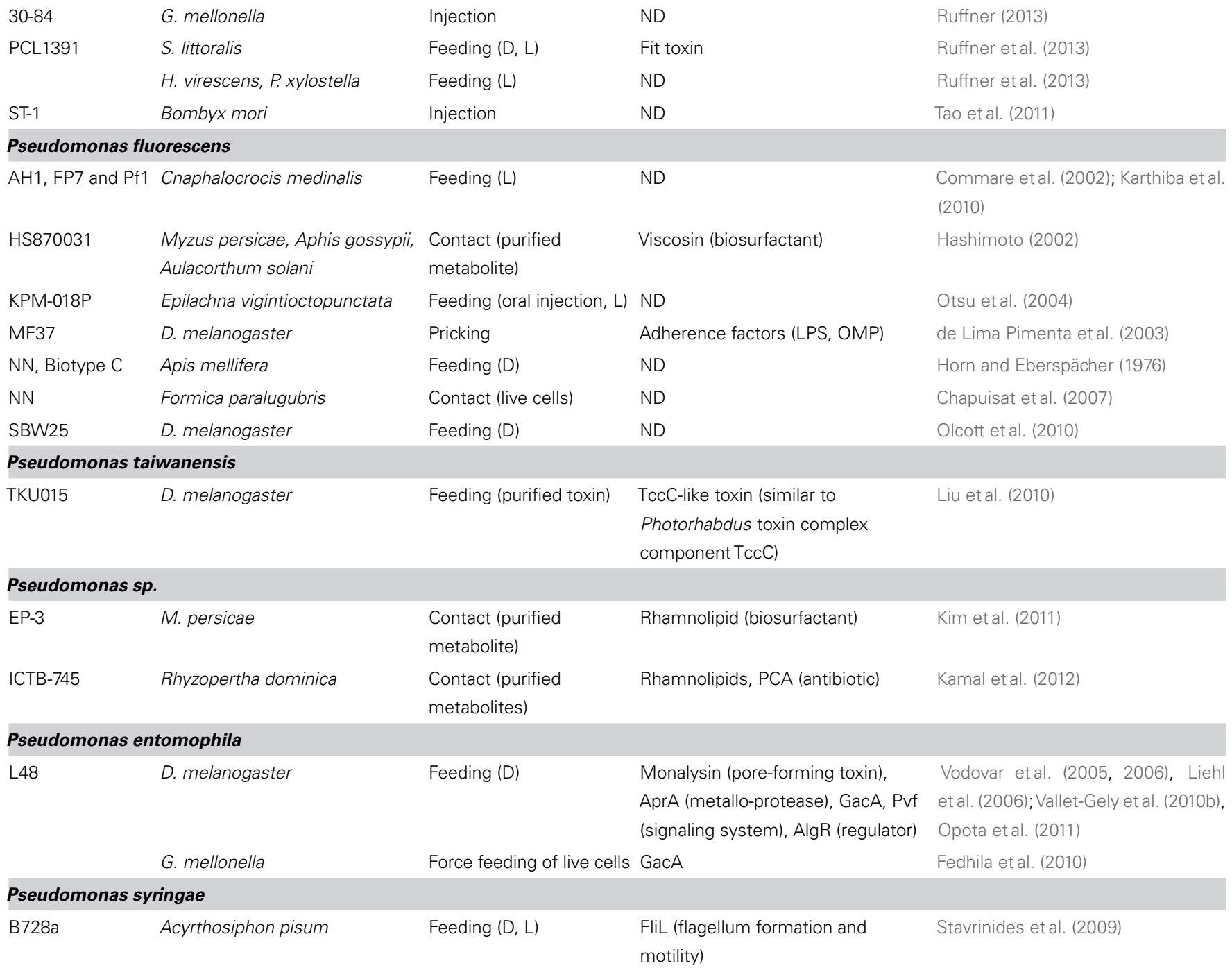

(Continued)

\section{Effector / regulatory mechanism Reference} involved in insect virulence ${ }^{c}$

Fit toxin (similar to Mcf toxin of Péchy-Tarr et al. $(2008,2013)$

Photorhabdus)

Fit toxin, GacA (global regulator of Ruffner etal. (2013) virulence and biocontrol)

ND Ruffner etal. (2013)

HCN (biocide) Devi and Kothamasi (2009)

Fit toxin Péchy-Tarr et al. (2008)

GacA

Olcott et al. (2010)

Orfamide (biosurfactant)_ Jang et al. (2013) 
Table 2 | Continued

\begin{tabular}{|c|c|c|c|c|}
\hline Bacterial strain $^{\mathrm{a}}$ & Target insect & $\begin{array}{l}\text { Application of bacteria } \\
\text { / bacterial product }{ }^{b}\end{array}$ & $\begin{array}{l}\text { Effector / regulatory mechanism } \\
\text { involved in insect virulence }^{c}\end{array}$ & Reference \\
\hline \multicolumn{5}{|c|}{ Pseudomonas aeruginosa } \\
\hline $\mathrm{CHA}$ & D. melanogaster & Pricking & T3SS and effectors (ExoS) & $\begin{array}{l}\text { Fauvarque et al. (2002), } \\
\text { Avet-Rochex et al. (2005) }\end{array}$ \\
\hline \multirow[t]{2}{*}{ PA14 } & G. mellonella & Injection & T3SS and effectors (ExoT, ExoU) & Miyata et al. (2003) \\
\hline & D. melanogaster & Feeding (D) & Quorum sensing (Rh|R) & Limmer etal. (2011) \\
\hline \multirow[t]{5}{*}{ PAO1 } & D. melanogaster & Injection & $\mathrm{HCN}$ & Broderick et al. (2008) \\
\hline & B. mori & Injection & $\begin{array}{l}\text { Superoxide dismutase (SodM, } \\
\text { SodB), exotoxin A, GacA }\end{array}$ & $\begin{array}{l}\text { Chieda etal. (2005, 2011), } \\
\text { liyama etal. (2007) }\end{array}$ \\
\hline & B. mori & Midgut injection & ExoS, pyoverdine (iron chelator) & Okuda etal. (2010) \\
\hline & D. melanogaster & Feeding (D) & $\begin{array}{l}\text { Quorum sensing (QscR), stringent } \\
\text { response (ppGpp), control of biofilm } \\
\text { formation }\end{array}$ & $\begin{array}{l}\text { Chugani etal. (2001); Mulcahy etal. } \\
\text { (2011), Vogt etal. (2011); de Bentz- } \\
\text { mann etal. (2012) }\end{array}$ \\
\hline & Pieris rapae & Feeding (D) & Quorum sensing (Lasl, Rhll) & Borlee et al. (2008) \\
\hline NN & Melanoplus bivittatus & Injection, Feeding (L) & ND & $\begin{array}{l}\text { Bucher and Stephens (1957), } \\
\text { Stephens (1958) }\end{array}$ \\
\hline
\end{tabular}

${ }^{a} N N$, not named.

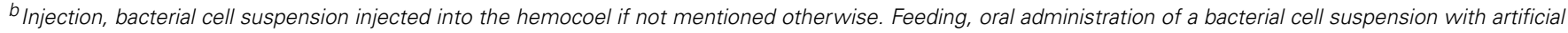
diet (D) or applied to plant leaves (L); Contact, bacterial cells or products sprayed on or put otherwise in contact with insect surface.

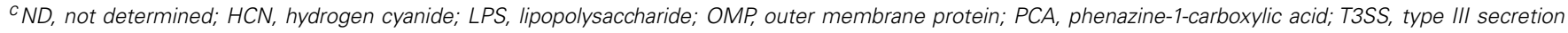
system.

While the transport of the Fit toxin still remains to be investigated, the roles and importance of the individual regulatory proteins of the Fit cluster have been elucidated and are described in more detail below. Because the putative BH3-like domain of Mcf1 is also conserved in the Fit toxin, it is imaginable that FitD induces apoptosis in insect cells as well.

So far the Fit toxin gene has been detected in the genomes of only a narrow group of plant-associated pseudomonads, namely in isolates of $P$. protegens and $P$. chlororaphis (Table 2; Loper et al., 2012; Ruffner et al., 2013; Shen et al., 2013). Strains of these two bacterial species generally showed a high toxicity toward larvae of lepidopteran insects. The P. protegens strains $\mathrm{CHA} 0$ and Pf- 5 were lethal to larvae of M. sexta and the greater wax moth Galleria mellonella upon injection of very low doses into the hemocoel of these insects (Péchy-Tarr et al., 2008). The Fit toxin thereby significantly contributed to the insecticidal activity of these microorganisms. Furthermore, as with Mcfl, heterologous expression of the Fit toxin in E. coli resulted in the capacity of the bacterium to kill the insect host upon injection.

P. protegens strain CHA0 and P. chlororaphis strain PCL1391 were later also shown to display potent oral insecticidal activity in feeding assays with artificial diet or leaves treated with the bacteria (Table 2; Ruffner et al., 2013). When bacterial suspensions containing low cell concentrations were sprayed on plant leaves, both strains efficiently killed larvae of several agriculturally important lepidopteran pest insects, notably the African cotton leafworm Spodoptera littoralis, the tobacco budworm Heliothis virescens, and the diamondback moth Plutella xylostella that fed on the leaves. The Fit toxin was found to substantially contribute to the oral insecticidal activity of the two model strains. In contrast, a related but naturally Fit-deficient $P$. fluorescens group strain displayed almost no oral toxicity in the same assay (Ruffner et al., 2013). Thus the presence of the Fit toxin gene in plant-colonizing pseudomonads seems to correlate well with high toxicity of these strains toward insects. This and observations with additional strains suggest that the gene could potentially be used as a suitable molecular marker for insecticidal activity in fluorescent pseudomonads (Ruffner et al., 2009; Ruffner, 2013). In addition to the Fit toxin, traits regulated by the GacS/GacA two-component system, which is known to control pathogenic and beneficial activities in pseudomonads (Haas and Keel, 2003; Lapouge et al., 2008), contribute significantly to the oral insecticidal activity of $P$. protegens $\mathrm{CHA} 0$ (Ruffner et al., 2013). Additional toxicity assays suggest specificity in the insecticidal spectrum of $P$. protegens CHA0. In particular, during a quest for potential side effects of the pseudomonad toward beneficial insects, the Fit toxin producers were found to exhibit no oral toxicity toward an ecologically and economically important pollinator, the large earth bumblebee Bombus terrestris (Ruffner, 2013).

The potential of these plant root-associated pseudomonads as entomopathogenic microorganisms can be demonstrated impressively by feeding Chinese cabbage leaves containing drops of a suspension of GFP-tagged P. protegens CHA0 to larvae of the large cabbage white Pieris brassicae. The bacteria seem to be capable of colonizing the insect gut and subsequently translocating into the hemocoel by so far unknown means, where they replicate and cause disease (Figure 1B). The invasion of the insect blood system within a short time period of less than 1 day after oral uptake of 
the microorganisms strongly suggests that these bacteria should be considered as true insect pathogens.

Because of the genetic organization of the fit cluster and the fact that the regulation of virulence in entomopathogenic bacteria has been addressed only to a limited extent at the molecular level before, it was particularly intriguing to study of the expression of the Fit toxin and its regulation. To this end the Fit toxin gene of $P$. protegens $\mathrm{CHA} 0$ was replaced at its native locus by a gene fusion of fitD to mcherry (coding for a red fluorescent protein), which allowed the direct in situ visualization and quantification of insect toxin production at wild-type level by monitoring and measuring the red fluorescence emitted by single cells with an epifluorescence microscope (Péchy-Tarr et al., 2013). The reporter strain expressed the Fit toxin only during an infection of insect larvae, but not when growing on plant roots or in common laboratory media. This indicated that the expression of the insect toxin is activated in a host-dependent manner and is tightly controlled in these bacteria. According to the current molecular model about the roles of the individual local regulators, all three proteins appear to be crucial for the observed tight regulation of toxin production in P. protegens CHA0 (Péchy-Tarr et al., 2013). The sensor histidine kinase-response regulator hybrid FitF is thought to perceive a yet unknown signal and to inactivate the repressor protein FitH by phosphorylation upon infection of an insect. This most probably releases the activator FitG, a member of the family of LysR-type transcriptional regulators, from the inhibition by FitH and leads to the activation of toxin expression. The observed production of the Fit toxin in insects and the molecular study of the three local regulators indicate that $P$. protegens is capable of detecting the insect host and of actively inducing the production of the Fit toxin during an infection of insect larvae.

However, the deletion of the Fit toxin gene in the chromosomes of $P$. protegens or $P$. chlororaphis strains is not sufficient to render them non-toxic to insects (Péchy-Tarr et al., 2008, 2013; Ruffner et al., 2013). This suggests that additional virulence factors are waiting to be discovered in these insecticidal pseudomonads. Candidate virulence factors that could play a role in insect pathogenicity in some of these strains are the so-called toxin complexes (Tc). Tc, which were first identified in P. luminescens, are large multimeric insecticidal protein complexes displayed on the surface of these bacteria (Bowen et al., 1998; ffrench-Constant et al., 2007). Although the exact mode of action of these orally active toxins is still not fully resolved, recent studies provide evidence that some Tc subunits function as a molecular syringe allowing membrane translocation of functional Tc components that induce actin clustering and death in target cells (Lang et al., 2010; Gatsogiannis et al., 2013). Tc components have also been investigated as alternatives to the Bt toxins for the development of transgenic crops (Liu et al., 2003). Tc-related gene clusters occur in many other bacteria that interact with insects, including Xenorhabdus nematophila, Yersinia pestis, Yersinia entomophaga, Serratia entomophila, and Bt (Hurst et al., 2000; Waterfield et al., 2001; Blackburn et al., 2011; Landsberg et al., 2011; Spinner et al., 2012). Remarkably, Tc-related genes can also be found in certain strains of P. chlororaphis and P. fluorescens (Loper et al., 2012) and their role in insect pathogenicity should thus be investigated in future studies. In pseudomonads, a role for a Tc-related gene so far has only been demonstrated for tccC from Pseudomonas taiwanensis of which the purified product caused substantial mortality when fed to larvae of Drosophila (Liu et al., 2010).

\section{MOLECULAR BASIS OF INSECT INTERACTION IN PROMINENT PATHOGENIC PSEUDOMONADS}

Several observations suggest that natural interactions of pseudomonads with insects are most likely more widespread than recognized so far. First, members of the genus Pseudomonas make commonly part of microbial communities of various insect species. Indeed, using culture-dependent and -independent approaches, pseudomonads were identified as common inhabitants of the intestinal tract or otherwise associated with field-collected or laboratory-raised larvae, pupae, and adults of representatives of the major insect orders. Examples include Anopheles, Aedes, and Culex mosquitoes, the Drosophila fruit fly, and the Hessian fly Mayetiola destructor in the order Diptera (Corby-Harris et al., 2007; Bansal etal., 2011; Osei-Poku et al., 2012), S. littoralis, the cotton bollworm Helicoverpa armigera, and the gypsy moth Lymantria dispar in the Lepidoptera (Broderick et al., 2004; Tang et al., 2012), the wireworm Limonius canus, the forest cockchafer Melolontha hippocastani, and Periplaneta and Blattella cockroaches in the Coleoptera (Lacey et al., 2007; Saitou et al., 2009; Arias-Cordero et al., 2012), Camponotus ants and several bee species in the Hymenoptera (Mohr and Tebbe, 2006; Li et al., 2012), and the leafhopper Homalodisca vitripennis and several aphids in the Hemiptera (Hashimoto, 2002; Lacava et al., 2007). Many of these insects feed on roots or aboveground parts of plants or spend a part of their life cycle in aquatic habitats, i.e., in environments that are typically colonized by pseudomonads. It is therefore likely that pseudomonads are commonly acquired by insects via ingestion or contact. These highly versatile bacteria then may be very well-adapted to live inside or otherwise associated with their arthropod host, exploiting it as a shelter, vector, or food source.

Second, the genomes of many Pseudomonas strains contain genetic loci with predicted function in insect interaction and insect toxicity. These loci are related to genes encoding known insect virulence determinants in the entomopathogens Photorhabdus and Xenorhabdus, namely the Mcf toxins, the Tc toxin complexes, the XaxAB cytolysin, and several lytic enzymes (ffrench-Constant et al., 2007; Vigneux et al., 2007; Lindeberg et al., 2008; Stavrinides et al., 2009; Silby et al., 2011; Loper et al., 2012). To date, the function of most of these loci in pseudomonads remains nebulous. A clear role in insect toxicity so far has only been established for the Mcf homolog Fit (see above).

Third, following oral infection several Pseudomonas species are capable not only of colonizing insects but also of exhibiting significant pathogenicity toward insects. Besides the above-described plant-beneficial $P$. protegens and $P$. chlororaphis of the $P$. fluorescens group (Mulet et al., 2012b), currently only three pathogenic species are known to be capable of efficiently killing insects, (i) the entomopathogen Pseudomonas entomophila, (ii) the opportunistic human pathogen Pseudomonas aeruginosa, and (iii) the plant pathogen $P$. syringae (Table 2). As detailed below, studies of the interactions of the three pathogens with insect hosts have significantly advanced our understanding of the molecular mechanisms 
involved in bacterial invasion of insects, escape from the insect immune response, gut and hemocoel colonization, and insect toxicity. They have also provided first insights into the ecology of vectoring of pseudomonads by insects. Studies on these pathogens can thus provide a valuable source of inspiration for future work on interactions of plant-beneficial pseudomonads with insects.

The entomopathogen P. entomophila is a bacterium that naturally infects Drosophila and originally was isolated from a fruit fly in Guadeloupe. The species which affiliates with the Pseudomonas putida phylogenetic group (Loper et al., 2012; Mulet et al., 2012a,b) is also pathogenic toward lepidopteran insects (Vallet-Gely et al., 2008; Fedhila et al., 2010). Following oral infection, this bacterium is capable of persisting in the gut of Drosophila, inducing local and systemic immune responses and, at high doses, of killing the insect, and thus constitutes an exciting model for studies into virulence and host immune defense mechanisms (Vodovar et al., 2005; Vallet-Gely et al., 2008, 2010b). P. entomophila virulence is multifactorial and depends on the GacS/GacA two-component system (Vodovar et al., 2005; Liehl et al., 2006). A second global regulatory system involving a yet unidentified signal molecule synthesized by the Pvf proteins contributes to control of P. entomophila virulence and immune response induction independently of GacS/GacA (Vallet-Gely et al., 2010b). Two important virulence factors have been identified in the entomopathogen. One is the Gac controlled metalloprotease AprA which counteracts the local immune response in the Drosophila gut via degradation of antimicrobial peptides (AMP) produced by the insect (Liehl et al., 2006). The other is a Gac and Pvf controlled pore-forming protein toxin termed Monalysin which contributes to the massive damage to the fly gut caused by $P$. entomophila in a mechanism involving suppression of immune and repair programs in the intestinal tract (Opota et al., 2011; Chakrabarti et al., 2012). However, both AprAand Monalysin-deficient mutants (but not gacA mutants) retain some degree of insect toxicity pointing to the existence of additional virulence factors. The genomic sequence of $P$. entomophila reveals a number of loci that encode potential candidate virulence factors, e.g., Tc-related toxins, HCN, hemolysins, and lipopeptides (Vodovar et al., 2006), which await to be explored. One of these factors, a lipopeptide with a role in hemolytic activity, was recently determined not to be required for virulence in Drosophila (Vallet-Gely et al., 2010a).

$P$. aeruginosa is an opportunistic human pathogen (Gellatly and Hancock, 2013) and several strains are capable of infecting mammalian, invertebrate (nematodes and insects) and plant hosts, and these multihost interactions can be used to unravel conserved and variable virulence strategies of the bacterium (Mahajan-Miklos et al., 2000; Hendrickson et al., 2001; Kim et al., 2008). In general, the capability of $P$. aeruginosa to infect and kill insects was not used to investigate insect pathogenicity of the bacterium per se but rather to profit of convenient infection models for exploring the molecular basis of virulence of the human pathogen, even more as insects rely on innate defense mechanisms resembling those in mammalian hosts to fight microbial infections (Vallet-Gely et al., 2008). The entomopathogenic potential of the species was recognized already in reports dating back to the early last century (Bacot, 1911; Cameron, 1934; Bucher and Stephens, 1957; Angus, 1965). For instance, a $P$. aeruginosa isolate was reported to be responsible for a disease in laboratory rearings of grasshoppers (Bucher and Stephens, 1957). The authors demonstrated that the disease can be produced artificially by injecting the isolate into the hemocoel ( $\mathrm{LD}_{50}$ of $10-20$ cells per insect) or by feeding the insects with the bacterium ( $\mathrm{LD}_{50}$ of about $10^{4}$ cells per insect). A follow-up study then provided evidence for the passage of small numbers of the $P$. aeruginosa isolate from the gut into the hemocoel (Stephens, 1958). A field experiment with the isolate to control grasshoppers was not successful (Baird, 1958; Angus, 1965).

A majority of recent studies on $P$. aeruginosa insect virulence rely on variations of two Drosophila infection models, i.e., the fly nicking and fly feeding models thought to reflect acute or chronic infections, respectively (Sibley et al., 2008; Apidianakis and Rahme, 2009). In the nicking model rapid killing within 1-2 days after pricking flies with a needle dipped into a bacterial culture is observed, whereas the feeding model allows to monitor an extended infection process of 1-2 weeks after ingestion of a high concentration of bacteria by the flies. Using these models, considerable strain variation in virulence of $P$. aeruginosa to Drosophila was observed (Lutter et al., 2012) coinciding with similar observations for P. fluorescens group bacteria (Olcott et al., 2010). The variations in the pathogenicity are likely to mirror differences in the genomic equipage with relevant virulence genes and in the regulation of these genes in the different strains. Virulence gene expression by $P$. aeruginosa in the Drosophila intestinal tract and as a consequence insect pathogenicity is also influenced by other microorganisms present in the gut (Sibley et al., 2008).

As for P. entomophila, P. aeruginosa virulence toward Drosophila is multifactorial. Following ingestion, $P$. aeruginosa is able to colonize various parts of the Drosophila intestinal tract, counteract the insect immune defense, cross the intestinal barrier, and proliferate in the hemolymph (Sibley et al., 2008; Limmer et al., 2011; Mulcahy et al., 2011). Global regulatory mechanisms involved in virulence control such as quorum sensing (QS) and the ppGppmediated stringent response are essential for the infection process (Chugani et al., 2001; Limmer et al., 2011; Vogt et al., 2011). The importance of QS signaling in the insect gut is highlighted in another feeding model involving the small cabbage white Pieris rapae in which interruption of QS signaling by mutation or by a chemical inhibitor reduced the virulence of $P$. aeruginosa (Borlee et al., 2008). In a recent study, $P$. aeruginosa was found to be capable of establishing a biofilm infection in the Drosophila crop following ingestion, thereby inducing an AMP immune response in the fly (Mulcahy etal., 2011). Remarkably, a mutant defective in biofilm formation had an improved capacity to cross the intestinal barrier and to disseminate into the hemolymph and was more virulent than the wild-type parent (Mulcahy et al., 2011). By contrast, hyperbiofilm strains were markedly less virulent to flies, an observation that was confirmed by another study (de Bentzmann et al., 2012) and is in accordance with the common association of biofilm formation with chronic infection in P. aeruginosa (Gellatly and Hancock, 2013) and other bacterial pathogens.

Multiple virulence traits of $P$. aeruginosa have a role in the acute infection model of Drosophila (Kim et al., 2008), including the capacity to suppress the insect's AMP defense response (Apidianakis et al., 2005), HCN production (Broderick et al., 2008) 
and delivery of type III secretion system (T3SS) effectors (Fauvarque et al., 2002; Avet-Rochex et al., 2005). The variety of virulence factors contributing to acute infection is further highlighted by studies involving the silkworm Bombyx mori and the Galleria wax moth, two widely used lepidopteran model insects. The global regulator GacA (Chieda et al., 2005), the ADP-ribosylating exotoxin A (Chieda et al., 2011), and superoxide dismutases (Iiyama et al., 2007), but not pyocyanin (Chieda et al., 2008) contribute to injectable activity of $P$. aeruginosa in the silkworm model. Several T3SS effectors including ExoTare important for virulence in the Galleria injection model (Miyata et al., 2003). A T3SS effector (ExoS) is also required for virulence and translocation of $P$. aeruginosa from the midgut to the hemolymph in the Bombyx model (Okuda et al., 2010).

P. syringae is an important member of the phyllosphere bacterial community and well-known for its plant pathogenic, icenucleating, and epiphytic activities (Hirano and Upper, 2000). However, possible activities of $P$. syringae in interactions with insects so far have attracted only little attention. Interestingly, a recent study suggests that at least some $P$. syringae strains may exhibit significant insecticidal activity (Stavrinides et al., 2009). In the study, the bean pathogen P. syringae pv. syringae B728a was found to kill the pea aphid Acyrthosiphon pisum within less than 2 days when fed to the insect in artificial diet. By contrast, the tomato pathogen P. syringae pv. tomato DC3000 did not harm the aphid even though cell densities of the strain in infected insects raised to higher levels than those of strain B728a. In another study, P. syringae pv. mori did not survive in the intestinal tract of Bombyx mori larvae fed an artificial diet containing the phytopathogen (Watanabe et al., 1998). This may suggest that, as with strains of the $P$. fluorescens and $P$. aeruginosa groups, the capacity for potent insect pathogenicity is associated only with certain $P$. syringae pathovars or strains and as such depends on the genomic background of the respective strain. The molecular basis of aphid toxicity of P. syringae pv. syringae B728a is unclear. Similarly to many other $P$. syringae strains, the genome of B728a harbors sequences related to those encoding the Photorhabdus Tc toxin complexes (Lindeberg et al., 2008). However, these were not required for virulence of $P$. syringae $\mathrm{B} 728 \mathrm{a}$ in the aphid model (Stavrinides et al., 2009).

The work of Stavrinides and colleagues puts forward another interesting aspect of Pseudomonas-insect associations. They show that following natural infection of pea aphids by $P$. syringae present on leaves, the bacteria multiply inside the insect host and then can be spread at high cell concentrations onto fresh leaf surfaces in the honeydew deposited by the aphids (Stavrinides etal., 2009; Nadarasah and Stavrinides, 2011). Only very few other reports provide experimental evidence for insect vectoring of pseudomonads. For instance, the root-associated bacterium P. chlororaphis was demonstrated to be transmitted between corn plants by the Southern corn rootworm Diabrotica undecimpunctata howardi feeding on roots colonized by the bacterium (Snyder et al., 1998). In other reports, $P$. fluorescens strains were found to persist in the gut of the Colorado potato beetle Leptinotarsa decemlineata fed with the bacteria in laboratory experiments or prior to overwintering in the field (Castrillo et al., 2000a,b). The ice-nucleation active bacteria markedly increased the supercooling point of the insects, leading the authors to speculate on a possibility for the biological control of the freeze-intolerant pest insects by reducing the survival of overwintering populations with a Pseudomonas treatment. Finally, insects may also be considered as potential vectors for the dispersal of biocontrol pseudomonads. This is documented by field experiments in which honeybees were successfully used to disseminate P. fluorescens strain A506, a biocontrol agent of fire blight and the active ingredient of the commercial product BlightBan A506, to pear and apple blossoms (Johnson etal., 1993). Together, all these studies illustrate that insects may not only constitute alternatives hosts for pseudomonads but also may serve as vectors and shelters for their survival and multiplication.

\section{POTENTIAL OF PSEUDOMONADS FOR THE CONTROL OF ROOT-FEEDING PEST INSECTS}

As it was illustrated in earlier chapters of this review, natural isolates of $P$. protegens and P. chlororaphis possess multiple activities that are beneficial to the plant in terms of growth and protection against various pests. These include antagonism of soil-borne phytopathogens, plant growth promotion, induction of systemic resistance, and insect pathogenicity (Figure 1). It is therefore that these bacteria have a high potential as plant protection products. Because they can promote the growth of plants and protect plant roots against several pests simultaneously, Pseudomonasbased formulations may become products of high profit potential (Chandler et al., 2011). While plant root-associated pseudomonads have been successfully used for the formulation of commercial fungicides (Fravel, 2005; Berg, 2009), no insecticidal products with Pseudomonas strains as active ingredient currently exist on the market for biopesticides.

The way to a product based on root-associated pseudomonads for efficient plant protection against insects and phytopathogenic fungi obviously is not free of obstacles. Pseudomonads are known to be challenging microorganisms when it comes to formulation (Walsh etal., 2001). The survival of the bacteria during the manufacturing process and long-term storage is a critical issue. Furthermore, Pseudomonas-based products were reported to exhibit inconsistency under field conditions and they have raised some concerns of the general public about biosafety because this bacterial genus includes opportunistic human pathogens such as $P$. aeruginosa. As with every new biopesticide, the expensive and time-consuming registration procedure is a major hurdle for the successful application of a biocontrol agent (Bale et al., 2008). Nevertheless, the few strains of the P. fluorescens group which are approved in many countries for their use as fungicides in agriculture already went through the evaluation of environmental risks and the registration procedure. The products passed all tests on biosafety and efficacy, and these bacterial strains should therefore be studied for their effects on insects to possibly extend their application range in the future by modifying their formulations.

Novel Pseudomonas strains can also readily be isolated from various insect species. An obvious approach to discover strains with entomopathogenic potential could therefore be the isolation of pseudomonads from the respective target organism. During the selection of strains for a new plant protection product 
the efficacy of the bacterium as an insecticidal organism, the persistence and competition on plant roots, and the resistance during the formulation process should be considered (Walsh et al., 2001). Moreover, a detailed risk analysis needs to be performed to ensure that the bacterial strains have no deleterious effects on human health and on the environment. This requires amongst others more research on the molecular basis and regulation of insecticidal activity in these root-associated pseudomonads. The importance of such investigations is impressively illustrated by the above-described discovery of the sophisticated regulatory switch allowing $P$. protegens to launch Fit toxin expression specifically in an insect host while arresting production of the insecticidal factor on roots (Péchy-Tarr et al., 2013), thus procuring a natural containment mechanism for biocontrol. The collaboration of the scientific community with commercial companies may then be the key to the development and commercialization of new biopesticides based on entomopathogenic, root-associated Pseudomonas strains, just like the development of products such as Proradix, Cedomon, and Cerall already has demonstrated (Johnsson et al., 1998; Buddrus-Schiemann et al., 2010).

Microbial control agents are considered environmentally friendly and harmless to mammals, making them ideal components of IPM systems. Commercial insecticides based on entomopathogenic bacteria are mostly applied as inundative releases for short-term pest control when insect populations have already reached a certain threshold (Lacey et al., 2001). Many strains of the $P$. fluorescens group are well-adapted to the life on plant roots and show environmental persistence. These microbes are very competitive and aggressive root colonizers (Lugtenberg and Kamilova, 2009), and would thus ideally be applied as inoculations for long-term control before pest insects pose a problem to the particular plant population. As for the commercially available Pseudomonas-based biofungicides, it could be possible to apply entomopathogenic strains of $P$. protegens and $P$. chlororaphis as seed coatings for inoculative releases and thereby use these microorganisms in a preventative manner. Because plant-associated pseudomonads are already successfully used as biological fungicides in agriculture, insecticidal products for crop protection with entomopathogenic Pseudomonas bacteria as active ingredient could fit well into integrated systems. They would extend the existing toolbox for IPM and help to optimize the protection of plants against pest insects that feed on roots during at least a part of their life cycle and remain a challenging problem in many agricultural systems. As mentioned before, formulations with plant-beneficial pseudomonads

\section{REFERENCES}

Almario, J., Prigent-Combaret, C., Muller, D., and Moënne-Loccoz, Y. (2013). Effect of clay mineralogy on iron bioavailability and rhizosphere transcription of 2,4-diacetylphloroglucinol biosynthetic genes in biocontrol Pseudomonas protegens. Mol. Plant Microbe Interact. 26, 566-574. doi: 10.1094/MPMI-11-12-0274-R

Angus, T. A. (1965). Symposium on microbial insecticides. I. Bacterial pathogens of insects as microbial insecticides. Bacteriol. Rev. 29, 364 372.

Apidianakis, Y., Mindrinos, M. N., Xiao, W., Lau, G. W., Baldini, R. L., Davis, R. W., et al. (2005). Profiling early infection responses: Pseudomonas aeruginosa eludes host defenses by suppressing antimicrobial peptide gene expression. Proc. Natl. Acad. Sci. U.S.A. 102, 2573-2578. doi: 10.1073/pnas. 0409588102

possessing insecticidal activity could potentially be developed to provide products to the farmers that may permit long-term control of root-feeding insects and soil-borne phytopathogens simultaneously in an IPM framework. Future research should investigate the interaction of these pseudomonads with other IPM components. Combinations with other biocontrol agents such as entomopathogenic fungi or nematodes or further IPM tactics could show a synergistic effect on the suppression of plant pests (Lacey et al., 2001; Lacey and Shapiro-Ilan, 2008; Karthiba et al., 2010; Hol et al., 2013).

The analysis and comparison of whole genome sequences in order to find candidate genes or gene clusters contributing to the insecticidal activity is a powerful approach to discover novel virulence factors and to extend the knowledge about these bacteria. It is further important to learn from existing data on other entomopathogenic bacteria to get a better understanding of the relevant virulence factors and their regulation, the mechanisms of colonization and invasion, and other functions required for insect pathogenicity of the plant-beneficial Pseudomonas strains. This includes in particular research on Photorhabdus/Xenorhabdus and pathogenic Pseudomonas species, but also studies about less known bacteria capable of killing insects, e.g., the aphid-infecting plant pathogen Dickeya dadantii (Costechareyre et al., 2013), could be inspiring for future investigations. Moreover, it is fundamental to carry out future research related to the control of soil-dwelling pest insects by beneficial root-associated pseudomonads under (near) natural conditions. This implies investigations into the interactions of these biocontrol bacteria with the natural microbiota of the insect gut just as the assessment of the efficacy of killing of insects under field conditions. Such approaches may help lessen known problems of inconsistency of Pseudomonas-based products in the field from the beginning.

We think that the current knowledge about the insect pathogenicity of certain root-associated pseudomonads and the powerful tools that are available for further investigations into this exciting feature are promising and a motivation for the development and application of microbial pesticides based on well-selected strains of these bacteria for a better management of root-feeding pest insects in the near future.

\section{ACKNOWLEDGMENTS}

We thank Erika Yashiro for careful reading of the manuscript. We gratefully acknowledge financial support from the Swiss National Foundation for Scientific Research (Projects 31003A_138248 and 406840_143141 NRP 68).

Apidianakis, Y., and Rahme, L. G. (2009). Drosophila melanogaster as a model host for studying Pseudomonas aeruginosa infection. Nat. Protoc. 4, 1285-1294. doi: 10.1038/ nprot.2009.124

Arias-Cordero, E., Ping, L., Reichwald, K., Delb, H., Platzer, M. and Boland, W. (2012). Comparative evaluation of the gut microbiota associated with the below- and aboveground life stages (larvae and beetles) of the forest cockchafer, Melolontha hippocastani. PLoS ONE 7:e51557. doi: 10.1371/journal.pone.0051557

Avet-Rochex, A., Bergeret, E., Attree, I., Meister, M., and Fauvarque, M. O. (2005). Suppression of Drosophila cellular immunity by directed expression of the ExoS toxin GAP domain of Pseudomonas aeruginosa. Cell. Microbiol. 7, 799-810. doi: 10.1111/j.14625822.2005.00512.x

Bacot, A. W. (1911). The persistence of Bacillus pyocyaneusin pupae and imagines of Muscadomestica raised 
from larvae experimentally infected with the bacillus. Parasitology 4, 6873. doi: $10.1017 /$ S0031182000002468 Baird, R. B. (1958). Field experiments with Pseudomonas aeruginosa (Schroeter) Migula to control grasshoppers. Can. Entomol. 90, 8991. doi: 10.4039/Ent9089-2

Bakker, P. A. H. M., Pieterse, C. M. J., and Van Loon, L. C. (2007). Induced systemic resistance by fluorescent Pseudomonas spp. Phytopathology 97, 239-243. doi: 10.1094/PHYTO-972-0239

Bale, J. S., van Lenteren, J. C., and Bigler, F. (2008). Biological control and sustainable food production. Philos. Trans. R. Soc. Lond. B Biol. Sci. 363, 761-776. doi: 10.1098/rstb. 2007.2182

Balmer, D., Planchamp, C., and MauchMani, B. (2013).On the move: induced resistance in monocots. $J$. Exp. Bot. 64, 1249-1261. doi: $10.1093 /$ jxb/ers 248

Bansal, R., Hulbert, S., Schemerhorn, B., Reese, J. C., Whitworth, R. J., Stuart, J. J., etal. (2011). Hessian fly-associated bacteria: transmission, essentiality, and composition. PLoS ONE 6:e23170. doi: 10.1371/journal.pone.0023170

Berendsen, R. L., Pieterse, C. M. J., and Bakker, P. A. H. M. (2012). The rhizosphere microbiome and plant health. Trends Plant Sci. 17, 478-486. doi: 10.1016/j.tplants.2012.04.001

Berg, G. (2009). Plant-microbe interactions promoting plant growth and health: perspectives for controlled use of microorganisms in agriculture. Appl. Microbiol. Biotechnol. 84, 11-18. doi: 10.1007/s00253-0092092-7

Bizzarri, M. F., and Bishop, A. H. (2008). The ecology of Bacillus thuringiensis on the phylloplane: colonization from soil, plasmid transfer, and interaction with larvae of Pieris brassicae. Microb. Ecol. 56, 133-139. doi: 10.1007/s00248-007-9331-1

Bjørnlund, L., Rønn, R., Péchy-Tarr, M., Maurhofer, M., Keel, C., and Nybroe, O. (2009). Functional GacS in Pseudomonas DSS73 prevents digestion by Caenorhabditis elegans and protects the nematode from killer flagellates. ISME J. 3, 770-779. doi: 10.1038/ismej.2009.28

Blackburn, M. B., Martin, P. A. W., Kuhar, D., Farrar, R. R. Jr., and Gundersen-Rindal, D. E. (2011). The occurrence of Photorhab$d u s$-like toxin complexes in Bacillus thuringiensis. PLoS ONE 6:e18122. doi: 10.1371/journal.pone.0018122

Blossey, B., and Hunt-Joshi, T. R. (2003). Belowground herbivory by insects: influence on plants and aboveground herbivores. Annu. Rev. Entomol. 48, 521547. doi: 10.1146/annurev.ento.48. 091801.112700

Bode, H. B. (2009). Entomopathogenic bacteria as a source of secondary metabolites. Curr. Opin. Chem. Biol. 13, 224-230. doi: 10.1016/j.cbpa.2009.02.037

Borlee, B. R., Geske, G. D., Robinson, C. J., Blackwell, H. E., and Handelsman, J. (2008). Quorum-sensing signals in the microbial community of the cabbage white butterfly larval midgut. ISME J. 2, 1101-1111. doi: 10.1038/ismej.2008.70

Bowen, D., Rocheleau, T. A., Blackburn, M., Andreev, O., Golubeva, E. Bhartia, R., et al. (1998). Insecticidal toxins from the bacterium Photorhabdus luminescens. Science 280, 2129-2132. doi: 10.1126/science.280. 5372.2129

Bravo, A., Gill, S. S., and Soberón, M. (2007). Mode of action of Bacillus thuringiensis Cry and Cyt toxins and their potential for insect control. Toxicon 49, 423-435. doi: 10.1016/j.toxicon.2006.11.022

Bravo, A., Likitvivatanavong, S., Gill, S. S., and Soberón, M. (2011). Bacillus thuringiensis: a story of a successful bioinsecticide. Insect Biochem. Mol. Biol. 41, 423-231. doi: 10.1016/j.ibmb.2011.02.006

Broderick, K. E., Chan, A., Balasubramanian, M., Feala, J., Reed, S. L., Panda, M., et al. (2008). Cyanide produced by human isolates of $\mathrm{Pseu}$ domonas aeruginosa contributes to lethality in Drosophila melanogaster. J. Infect. Dis. 197, 457-464. doi: 10.1086/525282

Broderick, N. A., Raffa, K. F., Goodman, R. M., and Handelsman, J. (2004). Census of the bacterial community of the gypsy moth larval midgut by using culturing and culture-independent methods. Appl. Environ. Microbiol. 70, 293-300. doi: 10.1128/AEM.70.1.293-300.2004

Bucher, G. E., and Stephens, J. M. (1957). A disease of grasshoppers caused by the bacterium Pseudomonas aeruginosa (Schroeter) Migula. Can. J. Microbiol. 3, 611-625. doi: 10.1139/m57-067

Buddrus-Schiemann, K., Schmid, M., Schreiner, K., Welzl, G., and Hartmann, A. (2010). Root colonization by Pseudomonas sp. DSMZ 13134 and impact on the indigenous rhizosphere bacterial community of barley. Microb. Ecol. 60, 381-393. doi: 10.1007/s00248-010-9720-8

Cameron, G. R. (1934). Inflammation in the caterpillars of Lepidoptera. J.
Pathol. Bacteriol. 38, 441-466. doi: 10.1002/path.1700380313

Campos-Herrera, R., Barbercheck, M., Hoy, C. W., and Stock, S. P. (2012). Entomopathogenic nematodes as a model system for advancing the frontiers of ecology. J. Nematol. 44, 162-176.

Castrillo, L. A., Lee, R. E. Jr., Lee, M. R., and Rutherford, S. T. (2000a). Identification of ice-nucleating active Pseudomonas fluorescens strains for biological control of overwintering Colorado potato beetles (Coleoptera: Chrysomelidae). J. Econ. Entomol. 93, 226-233. doi: 10.1603/0022-049393.2.226

Castrillo, L. A., Lee, R. E. Jr., Lee, M. R., and Wyman, J.A. (2000b). Long-term retention of ice-nucleating active Pseudomonas fluorescens by overwintering Colorado potato beetles. Cryo Letters 21, 5-12.

Chakrabarti, S., Liehl, P., Buchon, N., and Lemaitre, B. (2012). Infectioninduced host translational blockage inhibits immune responses and epithelial renewal in the Drosophila gut. Cell Host Microbe 12, 60-70. doi: 10.1016/j.chom.2012.06.001

Chandler, D., Bailey, A. S., Tatchell, G. M., Davidson, G., Greaves, J. and Grant, W. P. (2011). The development, regulation and use of biopesticides for integrated pest management. Philos. Trans. R. Soc Lond. B Biol. Sci. 366, 1987-1998. doi: 10.1098/rstb.2010.0390

Chapuisat, M., Oppliger, A., Magliano, P., and Christe, P. (2007). Wood ants use resin to protect themselves against pathogens. Proc. Biol. Sci. 274, 2013-2017. doi: 10.1098/rspb.2007.0531

Chieda, Y., Iiyama, K., Lee, J. M., Kusakabe, T., Yasunaga-Aoki, C., and Shimizu, S. (2008). Inactivation of pyocyanin synthesis genes has no effect on the virulence of Pseudomonas aeruginosa PAO toward the silkworm, Bombyx mori. FEMS Microbiol. Lett. 278, 101107. doi: 10.1111/j.1574-6968.2007. 00982.x

Chieda, Y., Iiyama, K., Lee, J. M., Kusakabe, T., Yasunaga-Aoki, C., and Shimizu, S. (2011). Virulence of an exotoxin A-deficient strain of Pseudomonas aeruginosa toward the silkworm, Bombyx mori. Microb. Pathog. 51, 407-414. doi: 10.1016/j.micpath.2011.09.002

Chieda, Y., Iiyama, K., YasunagaAoki, C., Lee, J. M., Kusakabe, T., and Shimizu, S. (2005). Pathogenicity of gacA mutant of Pseudomonas aeruginosa PA01 in the silkworm, Bombyx mori. FEMS
Microbiol. Lett. 244, 181-186. doi: 10.1016/j.femsle.2005.01.032

Chin-A-Woeng, T. F., Thomas-Oates, J. E., Lugtenberg, B. J., and Bloemberg, G. V. (2001). Introduction of the phzH gene of Pseudomonas chlororaphis PCL1391 extends the range of biocontrol ability of phenazine-1-carboxylic acidproducing Pseudomonas spp. strains. Mol. Plant Microbe Interact. 14, 10061015. doi: 10.1094/MPMI.2001.14. 8.1006

Chugani, S. A., Whiteley, M., Lee, K. M., D’Argenio, D., Manoil, C., and Greenberg, E. P. (2001). QscR, a modulator of quorum-sensing signal synthesis and virulence in Pseudomonas aeruginosa. Proc. Natl. Acad. Sci. U.S.A. 98, 2752-2757. doi: 10.1073/pnas.051624298

Commare, R. R., Nandakumar, R., Kandan, A., Suresh, S., Bharathi, M., Raguchander, T., et al. (2002). Pseudomonas fluorescens based bioformulation for the management of sheath blight disease and leaffolder insect in rice. Crop Prot. 21, 671-677. doi: 10.1016/S0261-2194 (02)00020-0

Cook, R. J., Thomashow, L. S., Weller, D. M., Fujimoto, D., Mazzola, M., Bangera, G., et al. (1995). Molecular mechanisms of defense by rhizobacteria against root disease. Proc. Natl. Acad. Sci. U.S.A. 92, 4197-4201. doi: 10.1073/pnas.92.10.4197

Corby-Harris, V., Pontaroli, A. C., Shimkets, L. J., Bennetzen, J. L., Habel, K. E., and Promislow, D. E. (2007). Geographical distribution and diversity of bacteria associated with natural populations of Drosophila melanogaster. Appl. Environ. Microbiol. 73, 3470-3479. doi: 10.1128/AEM.02120-06

Cornelis, P. (2010). Iron uptake and metabolism in pseudomonads. Appl. Microbiol. Biotechnol. 86, 1637-1645. doi: 10.1007/ s00253-010-2550-2

Cory, J. S., and Franklin, M. T. (2012). Evolution and the microbial control of insects. Evol. Appl. 5, 455469. doi: 10.1111/j.1752-4571.2012. 00269.x

Cory, S., and Adams, J. M. (2002). The $\mathrm{Bcl} 2$ family: regulators of the cellular life-or-death switch. Nat. Rev. Cancer 2, 647-656. doi: 10.1038/nrc883

Costechareyre, D., Chich, J. F., Strub, J. M., Rahbé, Y., and Condemine, G. (2013). Transcriptome of Dickeya dadantii infecting Acyrthosiphon pisum reveals a strong defense against antimicrobial peptides. PLoS ONE 8:e54118. doi: 10.1371/journal.pone. 0054118 
Crickmore, N., Baum, J., Bravo, A., Lereclus, D., Narva, K., Sampson, K., et al. (2013). Bacillus thuringiensis toxin nomenclature. Available at: http://www.btnomenclature.info/

Crickmore, N., Zeigler, D. R., Feitelson, J., Schnepf, E., Van Rie, J., Lereclus, D., et al. (1998). Revision of the nomenclature for the Bacillus thuringiensis pesticidal crystal proteins. Microbiol. Mol. Biol. Rev. 62, 807-813.

Daborn, P. J., Waterfield, N., Silva, C. P., Au, C. P., Sharma, S., and ffrenchConstant, R. H. (2002). A single Photorhabdus gene, makes caterpillars floppy ( $m c f)$, allows Escherichia coli to persist within and kill insects. Proc. Natl. Acad. Sci. U.S.A. 99, 10742 10747. doi: 10.1073/pnas.102068099

Daval, S., Lebreton, L., Gazengel, K., Boutin, M., Guillerm-Erckelboudt, A. Y., and Sarniguet, A. (2011). The biocontrol bacterium Pseudomonas fluorescens Pf29Arp strain affects the pathogenesis-related gene expression of the take-all fungus Gaeumannomyces graminis var. tritici on wheat roots. Mol. Plant Pathol. 12, 839-854. doi: 10.1111/j.13643703.2011.00715.x

de Bentzmann, S., Giraud, C., Bernard, C. S., Calderon, V., Ewald, F., Plésiat, P., et al. (2012). Unique biofilm signature, drug susceptibility and decreased virulence in Drosophila through the Pseudomonas aeruginosa two-component system PprAB. PLoS Pathog. 8:e1003052. doi: 10.1371/journal.ppat.1003052

Degenhardt, J., Hiltpold, I., Köllner, T. G., Frey, M., Gierl, A., Gershenzon, J., et al. (2009). Restoring a maize root signal that attracts insect-killing nematodes to control a major pest. Proc. Natl. Acad. Sci. U.S.A. 106, 13213-13218. doi: 10.1073/iti3209106

de Lima Pimenta, A., Di Martino, P., Le Bouder, E., Hulen, C., and Blight, M. A. (2003). In vitro identification of two adherence factors required for in vivo virulence of Pseudomonas fluorescens. Microb. Infect. 5, 1177-1187. doi: 10.1016/j.micinf.2003.09.002

Denno, R. F., Gruner, D. S., and Kaplan, I. (2008). Potential for entomopathogenic nematodes in biological control: a meta-analytical synthesis and insights from trophic cascade theory. J. Nematol. 40, 61-72.

Devi, K. K., and Kothamasi, D. (2009). Pseudomonas fluorescens CHA0 can kill subterranean termite Odontotermes obesus by inhibiting cytochrome c oxidase of the termite respiratory chain. FEMS Microbiol. Lett. 300, 195-200. doi: 10.1111/j.15746968.2009.01782.x
De Vleesschauer, D., and Höfte, M. (2009). Rhizobacteria-induced systemic resistance. Adv. Bot. Res. 51, 223-281. doi: 10.1016/S00652296(09)51006-3

de Werra, P., Baehler, E., Huser, A. Keel, C., and Maurhofer, M. (2008). Detection of plant-modulated alterations in antifungal gene expression in Pseudomonas fluorescens CHA0 on roots by flow cytometry. Appl. Environ. Microbiol. 74, 1139-1349. doi: 10.1128/AEM.02126-07

Dowling, A. J., Daborn, P. J., Waterfield, N. R., Wang, P., Streuli, C. H., and ffrench-Constant, R. H. (2004). The insecticidal toxin Makes caterpillars floppy (Mcf) promotes apoptosis in mammalian cells. Cell. Microbiol. 6, 345-353. doi: 10.1046/j.14625822.2003.00357.x

Ehlers, R. U. (2001). Mass production of entomopathogenic nematodes for plant protection. Appl. Microbiol. Biotechnol. 56, 623-633. doi: 10.1007/s002530100711

Fauvarque, M. O., Bergeret, E., Chabert, J., Dacheux, D., Satre, M., and Attree, I. (2002). Role and activation of type III secretion system genes in Pseudomonas aeruginosa-induced Drosophila killing. Microb. Pathog. 32, 287-295. doi: 10.1006/mpat.2002.0504

Fedhila, S., Buisson, C., Dussurget, O., Serror, P., Glomski, I. J., Liehl, P., et al. (2010). Comparative analysis of the virulence of invertebrate and mammalian pathogenic bacteria in the oral insect infection model Galleria mellonella. J. Invertebr. Pathol. 103, 24-29. doi: 10.1016/j.jip.2009. 09.005

ffrench-Constant, R. H., Dowl ing, A., and Waterfield, N. R. (2007). Insecticidal toxins from Photorhabdus bacteria and their potential use in agriculture. Toxicon 49, 436-451. doi: 10.1016/j. toxicon.2006.11.019

Fravel, D. R. (2005). Commercialization and implementation of biocontrol. Annu. Rev. Phytopathol. 43, 337359. doi: 10.1146/annurev.phyto.43. 032904.092924

Gatehouse, A. M., Ferry, N., Edwards, M. G., and Bell, H. A. (2011) Insect-resistant biotech crops and their impacts on beneficial arthropods. Philos. Trans. R. Soc. Lond. $B$ Biol. Sci. 366, 1438-1452. doi: $10.1098 /$ rstb. 2010.0330

Gatsogiannis, C., Lang, A. E., Meusch, D., Pfaumann, V., Hofnagel, O. Benz, R., et al. (2013). Syringe-like injection mechanism in Photorhabdus luminescens toxins. Nature 495, 520-523. doi: 10.1038/nature1 1987
Gellatly, S. L., and Hancock, R. E. (2013). Pseudomonas aeruginosa: new insights into pathogenesis and host defenses. Pathog. Dis. 67, 159-173. doi: 10.1111/2049-632X. 12033

Gray, M. E., Sappington, T. W., Miller, N. J., Moeser, J., and Bohn, M. O. (2009). Adaptation and invasiveness of Western corn rootworm: intensifying research on a worsening pest. Annu. Rev. Entomol. 54, 303321. doi: 10.1146/annurev.ento.54. 110807.090434

Gross, H., and Loper, J. E. (2009). Genomics of secondary metabolite production by Pseudomonas spp. Nat. Prod. Rep. 26, 1408-1446. doi: $10.1039 / \mathrm{b} 817075 \mathrm{~b}$

Haas, D., and Défago, G. (2005). Biological control of soil-borne pathogens by fluorescent pseudomonads. Nat. Rev. Microbiol. 3, 307-319. doi: 10.1038/nrmicro1129

Haas, D., and Keel, C. (2003). Regulation of antibiotic production in rootcolonizing Pseudomonas spp. and relevance for biological control of plant disease. Annu. Rev. Phytopathol. 41, 117-153. doi: 10.1146/annurev. phyto.41.052002.095656

Hashimoto, Y. (2002). Study of the bacteria pathogenic for aphids, isolation of bacteria and identification of insecticidal compound. Rep. Hokkaido Prefectural Agric. Exp. Station 102, 1-48.

Heckel, D. G. (2012). Insecticide resistance after Silent spring. Science 337, 1612-1614. doi: 10.1126/science. 1226994

Hendrickson, E. L., Plotnikova, J., Mahajan-Miklos, S., Rahme, L. G., and Ausubel, F. M. (2001). Differential roles of the Pseudomonas aeruginosa PA14 rpoN gene in pathogenicity in plants, nematodes, insects, and mice. J. Bacteriol. 183 7126-7134. doi: 10.1128/JB.183.24 7126-7134.2001

Herbert, E. E., and Goodrich-Blair, H. (2007). Friend and foe: the two faces of Xenorhabdus nematophila. Nat. Rev. Microbiol. 5, 634-646. doi: 10.1038/nrmicro1706

Hirano, S. S., and Upper, C. D. (2000) Bacteria in the leaf ecosystem with emphasis on Pseudomonas syringae-a pathogen, ice nucleus, and epiphyte. Microbiol. Mol. Biol. Rev. 64, 624653. doi: 10.1128/MMBR.64.3.624 653.2000

Höfte, M., and Altier, N. (2010). Fluorescent pseudomonads as biocontrol agents for sustainable agricultural systems. Res. Microbiol. 161, 464-471. doi: 10.1016/j.resmic.2010. 04.007
Hol, W. H., Bezemer, T. M., and Biere, A. (2013). Getting the ecology into interactions between plants and the plant growth-promoting bacterium Pseudomonas fluorescens. Front. Plant Sci. 4:81. doi: 10.3389/fpls. 2013.00081

Horn, H., and Eberspächer, J. (1976). Die Waldtrachtkrankheit der Honigbiene ii. Nachweis von Bakterien in der Hämolymphe waldtrachtkranker Bienen und der zusätzliche Einfluss der Fütterung auf die Waldtrachtkrankheit. Apidologie 17, 307-324.

Hunter, M. D. (2001). Out of sight, out of mind: the impacts of root-feeding insects in natural and managed systems. Agric. Forest Entomol.3,3-9. doi: 10.1046/j.1461-9563. 2001.00083.x

Hurst, M. R., Glare, T. R., Jackson, T. A., and Ronson, C. W. (2000). Plasmid-located pathogenicity determinants of Serratia entomophila, the causal agent of amber disease of grass grub, show similarity to the insecticidal toxins of Photorhabdus luminescens. J. Bacteriol. 182, 51275138. doi: 10.1128/JB.182.18.51275138.2000

Iiyama, K., Chieda, Y., Lee, J. M., Kusakabe, T., Yasunaga-Aoki, C., and Shimizu, S. (2007). Effect of superoxide dismutase gene inactivation on virulence of Pseudomonas aeruginosa $\mathrm{PAO} 1$ toward the silkworm, Bombyx mori. Appl. Environ. Microbiol. 73, 1569-1575. doi: 10.1128/AEM.00981-06

James, C. (2012). Global Status of Commercialized Biotech/GM Crops: 2012. ISAAA Brief No. 44. Ithaca: ISAAA.

Jang, J. Y., Yang, S. Y., Kim, Y. C., Lee, C. W., Park, M. S., Kim, J. C., etal. (2013). Identification of orfamide $\mathrm{A}$ as an insecticidal metabolite produced by Pseudomonas protegens F6. J. Agric. Food Chem. doi: 10.1021/jf401218w [Epub ahead of print].

Janvier, C., Villeneuve, F., Alabouvette, C., Edel-Hermann, V., Mateille, T., and Steinberg, C. (2007). Soil health through soil disease suppression: Which strategy from descriptors to indicators? Soil Biol. Biochem. 39, 123. doi: 10.1016/j.soilbio.2006.07.001 Johnson, K. B., Stockwell, V. O., Burgett, D. M., Sugar, D., and Loper, J. E. (1993). Dispersal of Erwinia amylovora and Pseudomonas fluorescens by honey bees from hives to apple and pear blossoms. Phytopathology 83, 478-484. doi: 10.1094/Phyto-83-478

Johnsson, L., Hökeberg, M., and Gerhardson, B. (1998). Performance of 
the Pseudomonas chlororaphis biocontrol agent MA 342 against cereal seed-borne diseases in field experiments. Eur. J. Plant Pathol. 104 701-711.

Jousset, A., Rochat, L., Lanoue, A., Bonkowski, M., Keel, C., and Scheu, S. (2011). Plants respond to pathogen infection by enhancing the antifungal gene expression of root-associated bacteria. Mol. Plant Microbe Interact. 24, 352-358. doi: 10.1094/MPMI-0910-0208

Jousset, A., Rochat, L., Péchy-Tarr, M., Keel, C., Scheu, S., and Bonkowski, M. (2009). Predators promote defence of rhizosphere bacterial populations by selective feeding on non-toxic cheaters. ISME J. 3, 666-674. doi: 10.1038/ismej.2009.26

Kamal, A., Shaik, A. B., Kumar, C. G., Mongolla, P., Rani, P. U., Krishna, K. V., et al. (2012). Metabolic profiling and biological activities of bioactive compounds produced by Pseudomonas sp. strain ICTB-745 isolated from Ladakh, India. J. Microbiol. Biotechnol. 22, 69-79. doi: 10.4014/jmb.1105.05008

Karthiba, L., Saveetha, K., Suresh, S., Raguchander, T., Saravanakumar, D., and Samiyappan, R. (2010). PGPR and entomopathogenic fungus bioformulation for the synchronous management of leaffolder pest and sheath blight disease of rice. Pest Manag. Sci. 66, 555-564. doi: 10.1002/ps.1907

Keel, C., Voisard, C., Berling, C. H., Kahr, G., and Défago, G. (1989). Iron sufficiency is a prerequisite for suppression of tobacco black root rot by Pseudomonas fluorescens strain CHA0 under gnotobiotic conditions. Phytopathology 79, 584-589.

Kim, S. H., Park, S. Y., Heo, Y. J., and Cho, Y. H. (2008). Drosophila melanogaster-based screening for multihost virulence factors of Pseudomonas aeruginosa PA14 and identification of a virulenceattenuating factor, HudA. Infect. Immun. 76, 4152-4162. doi: 10.1128/ IAI.01637-07

Kim, S. K., Kim, Y. C., Lee, S., Kim, J.C., Yun, M. Y., and Kim, I. S. (2011). Insecticidal activity of rhamnolipid isolated from Pseudomonas sp. EP3 against green peach aphid (Myzus persicae). J. Agric. Food Chem. 59, 934-938. doi: 10.1021/jf104027x

Lacava, P. T., Parker, J., Andreote, F. D., Dini-Andreote, F., Ramirez, J. L., and Miller, T. A. (2007). Analysis of the bacterial community in glassy-winged sharpshooter heads. Entomol. Res. 37, 261-266. doi: 10.1111/j.1748-5967.2007.00123.x
Lacey, L. A., Frutos, R., Kaya, H. K., and Vail, P. (2001). Insect pathogens as biological control agents: do they have a future? Biol. Control 21, 230248. doi: 10.1006/bcon.2001.0938

Lacey, L. A., and Georgis, R. (2012). Entomopathogenic nematodes for control of insect pests above and below ground with comments on commercial production. J. Nematol. 44, 218-225.

Lacey, L. A., and Shapiro-Ilan, D. I (2008). Microbial control of insect pests in temperate orchard systems: potential for incorporation into IPM. Annu. Rev. Entomol. 53, 121144. doi: 10.1146/annurev.ento.53. 103106.093419

Lacey, L. A., Unruh, T. R., Simkins, H., and Thomsen-Archer, K. (2007). Gut bacteria associated with the Pacific Coast wireworm, Limonius canus, inferred from 16s rDNA sequences and their implications for control. Phytoparasitica 35, 479-489. doi: 10.1007/BF03020607

Landsberg, M. J., Jones, S. A., Rothnagel, R., Busby, J. N., Marshall, S. D., Simpson, R. M., et al. (2011). 3D structure of the Yersinia entomophaga toxin complex and implications for insecticidal activity. Proc. Natl. Acad. Sci. U.S.A. 108, 20544-20549. doi: 10.1073/pnas.1111155108

Lang, A. E., Schmidt, G., Schlosser, A. Hey, T. D., Larrinua, I. M., Sheets, J. J., et al. (2010). Photorhabdus luminescens toxins ADP-ribosylate actin and RhoA to force actin clustering. Science 327, 1139-1142. doi: 10.1126/science. 1184557

Lapouge, K., Schubert, M., Allain, F. H., and Haas, D. (2008). Gac/Rsm signal transduction pathway of gammaproteobacteria: from RNA recognition to regulation of social behaviour. Mol. Microbiol. 67, 241-253. doi: 10.1111/j.1365-2958.2007.06042.x

Li, X., Nan, X., Wei, C., and $\mathrm{He}$ H. (2012). The gut bacteria associated with Camponotus japonicus Mayr with culture-dependent and DGGE methods. Curr. Microbiol. 65, 610-616. doi: 10.1007/s00284-0120197-1

Liehl, P., Blight, M., Vodovar, N., Boccard, F., and Lemaitre, B. (2006). Prevalence of local immune response against oral infection in a Drosophila/Pseudomonas infection model. PLoS Pathog. 2:e56. doi: 10.1371/journal.ppat.0020056

Limmer, S., Haller, S., Drenkard, E., Lee, J., Yu, S., Kocks, C., et al. (2011). Pseudomonas aeruginosa RhIR is required to neutralize the cellular immune response in a Drosophila melanogaster oral infection model. Proc. Natl.
Acad. Sci. U.S.A. 108, 17378-17383 doi: 10.1073/pnas.1114907108

Lindeberg, M., Myers, C. R., Collmer, A., and Schneider, D. J. (2008). Roadmap to new virulence determinants in Pseudomonas syringae: insights from comparative genomics and genome organization. Mol. Plant Microbe Interact. 21, 685-700. doi: 10.1094/MPMI-21-6-0685

Liu, D., Burton, S., Glancy, T., Li, Z. S., Hampton, R., Meade, T., et al. (2003). Insect resistance conferred by 283-kDa Photorhabdus luminescens protein TcdA in Arabidopsis thaliana. Nat. Biotechnol. 21, 1222-1228. doi: 10.1038/nbt866

Liu, J.-R., Lin, Y.-D., Chang, S.-T., Zeng, Y.-F., and Wang, S.-L. (2010). Molecular cloning and characterization of an insecticidal toxin from Pseudomonas taiwanensis. J. Agric. Food Chem. 58, 12343-12349. doi: 10.1021/jf103604r

Loper, J. E., and Buyer, J. S. (1991) Siderophores in microbial interactions on plant surfaces. Mol. Plant Microbe Interact. 4, 5-13. doi: 10.1094/MPMI-4-005

Loper, J. E., Hassan, K. A., Mavrodi, D. V., Davis, E. W. II, Lim, C. K., Shaffer, B. T., et al. (2012) Comparative genomics of plantassociated Pseudomonas spp.: insights into diversity and inheritance of traits involved in multitrophic interactions. PLoS Genet. 8:e1002784. doi 10.1371/journal.pgen.1002784

Lugtenberg, B., and Kamilova, F. (2009). Plant-growth-promoting rhizobacteria. Annu. Rev. Microbiol. 63, 541556. doi: 10.1146/annurev.micro.62. 081307.162918

Lutter, E. I., Purighalla, S., Duong, J., and Storey, D. G. (2012). Lethality and cooperation of Pseudomonas aeruginosa quorum-sensing mutants in Drosophila melanogaster infection models. Microbiology 158, 2125-2132. doi: 10.1099/ mic.0.054999-0

Mahajan-Miklos, S., Rahme, L. G. and Ausubel, F. M. (2000). Elucidating the molecular mechanisms of bacterial virulence using nonmammalian hosts. Mol. Microbiol. 37, 981-988. doi: 10.1046/j.1365 2958.2000.02056.x

Marchi, M., Boutin, M., Gazengel, K., Rispe, C., Gauthier, J. P., Guillerm-Erckelboudt, A. Y., et al. (2013). Genomic analysis of the biocontrol strain Pseudomonas fluorescens Pf29Arp with evidence of T3SS and T6SS gene expression on plant roots. Environ. Microbiol. Rep. 5, 393-403. doi: 10.1111/1758-2229. 12048
Mark, G. L., Morrissey, J. P., Higgins, P., and O'Gara, F. (2006). Molecular-based strategies to exploit Pseudomonas biocontrol strains for environmental biotechnology applications. FEMS Microbiol. Ecol. 56, 167-177. doi: 10.1111/j.15746941.2006.00056.x

Maurhofer, M., Hase, C., Meuwly, P., Métraux, J.-P., and Défago, G. (1994). Induction of systemic resistance of tobacco to tobacco necrosis virus by the root-colonizing Pseudomonas fluorescens strain CHA0: influence of the gacA gene and of pyoverdine production. Phytopathology 84, 139-146.

Mavrodi, D. V., Peever, T. L., Mavrodi, O. V., Parejko, J. A., Raaijmakers, J. M., Lemanceau, P., et al. (2010). Diversity and evolution of the phenazine biosynthesis pathway. Appl. Environ. Microbiol. 76, 866-879. doi: 10.1128/AEM.02009-09

Mazurier, S., Corberand, T., Lemanceau, P., and Raaijmakers, J. M. (2009). Phenazine antibiotics produced by fluorescent pseudomonads contribute to natural soil suppressiveness to Fusarium wilt. ISME J. 3, 977-991. doi: 10.1038/ismej.2009.33

Mazzola, M. (2004). Assessment and management of soil microbial community structure for disease suppression. Annu. Rev. Phytopathol. 42, 35-59. doi: 10.1146/annurev.phyto. 42.040803.140408

Mendes, R., Kruijt, M., de Bruijn, I., Dekkers, E., van der Voort, M., Schneider, J. H. M., et al. (2011). Deciphering the rhizosphere microbiome for disease-suppressive bacteria. Science 332, 1097-1100. doi: 10.1126/science. 1203980

Mentel, M., Ahuja, E. G., Mavrodi, D. V., Breinbauer, R., Thomashow, L. S., and Blankenfeldt, W. (2009). Of two make one: the biosynthesis of phenazines. ChemBioChem 10, 22952304. doi: 10.1002/cbic.200900323

Mercado-Blanco, J., and Bakker, P. A. (2007). Interactions between plants and beneficial Pseudomonas spp.: exploiting bacterial traits for crop protection. Antonie Van Leeuwenhoek 92, 367-389. doi: 10.1007/s10482007-9167-1

Miyata, S., Casey, M., Frank, D. W., Ausubel, F. M., and Drenkard, E. (2003). Use of the Galleria mellonella caterpillar as a model host to study the role of the type III secretion system in Pseudomonas aeruginosa pathogenesis. Infect. Immun. 71, 2404-2413. doi: 10.1128/ IAI.71.5.2404-2413.2003

Mohr, K. I., and Tebbe, C. C. (2006). Diversity and phylotype consistency of bacteria in the guts of 
three bee species (Apoidea) at an oilseed rape field. Environ. Microbiol. 8, 258-272. doi: 10.1111/j.14622920.2005.00893.x

Monnerat, R. G., Soares, C. M., Capdeville, G., Jones, G., Martins, E. S., Praça, L., etal. (2009). Translocation and insecticidal activity of Bacillus thuringiensis living inside of plants. Microb. Biotechnol. 2, 512 520. doi: 10.1111/j.1751-7915.2009. 00116.x

Mulcahy, H., Sibley, C. D., Surette, M. G., and Lewenza, S. (2011). Drosophila melanogaster as an animal model for the study of Pseudomonas aeruginosa biofilm infections in vivo. PLoS Pathog. 7:e1002299. doi: 10.1371/journal.ppat.1002299

Mulet, M., Gomila, M., Lemaitre, B., Lalucat, J., and García-Valdés, E. (2012a). Taxonomic characterisation of Pseudomonas strain L48 and formal proposal of Pseudomonas entomophila sp. nov. Syst. Appl. Microbiol. 35, 145149. doi: 10.1016/j.syapm.2011. 12.003

Mulet, M., Gomila, M., Scotta, C., Sánchez, D., Lalucat, J., and García-Valdés, E. (2012b). Concordance between whole-cell matrixassisted laser-desorption/ionization time-of-flight mass spectrometry and multilocus sequence analysis approaches in species discrimination within the genus Pseudomonas. Syst. Appl. Microbiol. 35, 455464. doi: 10.1016/j.syapm.2012. 08.007

Mulet, M., Lalucat, J., and GarcíaValdés, E. (2010). DNA sequencebased analysis of the Pseudomonas species. Environ. Microbiol. 12, 15131530. doi: 10.1111/j.1462-2920.2010. 02181.x

Nadarasah, G., and Stavrinides, J. (2011). Insects as alternative hosts for phytopathogenic bacteria. FEMS Microbiol. Rev. 35, 555575. doi: 10.1111/j.1574-6976.2011. 00264.x

Nielsen-LeRoux, C., Gaudriault, S., Ramarao, N., Lereclus, D., and Givaudan, A. (2012). How the insect pathogen bacteria Bacillus thuringiensis and Xenorhabdus/Photorhabdus occupy their hosts. Curr. Opin. Microbiol. 15, 220-231. doi: 10.1016/j.mib.2012.04.006

Nielsen, T. H., and Sørensen, J. (2003). Production of cyclic lipopeptides by Pseudomonas fluorescens strains in bulk soil and in the sugar beet rhizosphere. Appl. Environ. Microbiol. 69, 861868. doi: 10.1128/AEM.69.2.861-868 2003
Oerke, E.-C. (2006). Crop losses to pests. J. Agric. Sci. 144, 31-43. doi: 10.1017/S0021859605005708

Okuda, J., Hayashi, N., Okamoto, M. Sawada, S., Minagawa, S., Yano, Y., et al. (2010). Translocation of Pseudomonas aeruginosa from the intestinal tract is mediated by the binding of ExoS to an Na,K-ATPase regulator, FXYD3. Infect. Immun. 78, 45114522. doi: 10.1128/IAI.00428-10

Olcott, M. H., Henkels, M. D., Rosen, K. L., Walker, F. L., Sneh, B., Loper, J. E., etal. (2010). Lethality and developmental delay in Drosophila melanogaster larvae after ingestion of selected Pseudomonas fluorescens strains. PLoS ONE 5:e12504. doi: 10.1371/journal.pone. 0012504

Opota, O., Vallet-Gély, I., Vincentelli, R., Kellenberger, C., Iacovache, I., Gonzalez, M. R., et al. (2011). Monalysin, a novel $\beta$-pore-forming toxin from the Drosophila pathogen Pseudomonas entomophila, contributes to host intestinal damage and lethality. PLoS Pathog. 7:e1002259. doi: 10.1371/ journal.ppat.1002259

Osei-Poku, J., Mbogo, C. M., Palmer, W. J., and Jiggins, F. M. (2012). Deep sequencing reveals extensive variation in the gut microbiota of wild mosquitoes from Kenya. Mol. Ecol. 21, 5138-5150. doi: 10.1111/j.1365294X.2012.05759.x

Otsu, Y., Matsuda, Y., Mori, H., Ueki, H., Nakajima, T., Fujiwara K., et al. (2004). Stable phylloplane colonization by entomopathogenic bacterium Pseudomonas fluorescens KPM-018P and biological control of phytophagous ladybird beetles Epilachna vigintioctopunctata (Coleoptera: Coccinellidae). Biocontrol Sci. Technol. 14, 427-439. doi: 10.1080/09583150410001683538

Park, J. Y., Oh, S. A., Anderson, A. J., Neiswender, J., Kim, J. C., and Kim, Y. C. (2011). Production of the antifungal compounds phenazine and pyrrolnitrin from Pseudomonas chlororaphis $\mathrm{O} 6$ is differentially regulated by glucose. Lett. Appl. Microbiol. 52, 532-537. doi: 10.1111/j.1472765X.2011.03036.x

Paulsen, I. T., Press, C. M., Ravel, J., Kobayashi, D. Y., Myers, G. S. Mavrodi, D. V., et al. (2005). Complete genome sequence of the plant commensal Pseudomonas fluorescen Pf-5. Nat. Biotechnol. 23, 873-878. doi: $10.1038 / n b t 1110$

Péchy-Tarr, M., Borel, N., Kupferschmied, P., Turner, V., Binggeli, O., Radovanovic, D., et al. (2013). Control and host-dependent activation of insect toxin expression in a rootassociated biocontrol pseudomonad. Environ. Microbiol. 15, 736-750. doi: 10.1111/1462-2920.12050

Péchy-Tarr, M., Bruck, D. J., Maurhofer, M., Fischer, E., Vogne, C., Henkels, M. D., et al. (2008). Molecular analysis of a novel gene cluster encoding an insect toxin in plant-associated strains of Pseudomonas fluorescens. Environ. Microbiol. 10, 2368-2386. doi: 10.1111/j. 1462-2920.2008.01662.x

Petzold-Maxwell, J. L., Jaronski, S. T., Clifton, E. H., Dunbar, M. W., Jackson, M. A., and Gassmann, A. J. (2013). Interactions among Bt maize, entomopathogens, and rootworm species (Coleoptera: Chrysomelidae) in the field: effects on survival, yield, and root injury. J. Econ. Entomol. 106, 622-632. doi: 10.1603/ EC12375

Pierson, L. S. III, and Pierson, E. A. (2010). Metabolism and function of phenazines in bacteria: impacts on the behavior of bacteria in the environment and biotechnological processes. Appl. Microbiol. Biotechnol. 86, 659-670. doi: 10.1007/s00253-010 2509-3

Pineda, A., Soler, R., Weldegergis, B. T., Shimwela, M. M. van Loon, J. J., and Dicke, M. (2013). Non-pathogenic rhizobacteria interfere with the attraction of parasitoids to aphid-induced plant volatiles via jasmonic acid signalling. Plant Cell Environ. 36, 393 404. doi: 10.1111/j.1365-3040.2012. 02581.x

Pineda, A., Zheng, S. J., van Loon, J. J., and Dicke, M. (2012). Rhizobacteria modify plant-aphid interactions: a case of induced systemic susceptibility. Plant Biol. (Stuttg.), 14(Suppl. 1), 83-90. doi: 10.1111/j.14388677.2011.00549.x

Prabakaran, G., Paily, K. P., Padmanabhan, V., Hoti, S. L., and Balaraman, K. (2002). Isolation of a Pseudomonas fluorescens metabolite/exotoxin active against both larvae and pupae of vector mosquitoes. Pest Manag. Sci. 59, 21-24. doi: 10.1002/ps.610

Prime-A-Plant Group: Conrath, U., Beckers, G. J., Flors, V., GarcíaAgustín, P., Jakab, G., et al. (2006) Priming: getting ready for battle. Mol. Plant Microbe Interact. 19, 1062-1071. doi: 10.1094/MPMI-191062

Raaijmakers, J. M., De Bruijn, I., Nybroe, O., and Ongena, M. (2010). Natural functions of lipopeptides from Bacillus and Pseudomonas: more than surfactants and antibiotics. FEMS Microbiol. Rev. 34, 1037-1062. doi: 10.1111/j.1574-6976.2010.00221.x

Raaijmakers, J. M., and Mazzola, M. (2012). Diversity and natural functions of antibiotics produced by beneficial and plant pathogenic bacteria. Annu. Rev. Phytopathol. 50, 403-424. doi: 10.1146/annurevphyto-081211-172908

Ramette, A., Frapolli, M., FischerLe Saux, M., Gruffaz, C., Meyer, J. M., Défago, G., et al. (2011). Pseudomonas protegens sp. nov., widespread plant-protecting bacteria producing the biocontrol compounds 2,4-diacetylphloroglucinol and pyoluteorin. Syst. Appl. Microbiol. 34, 180-188. doi: 10.1016/ j.syapm.2010.10.005

Raymond, B., Johnston, P. R., NielsenLeRoux, C., Lereclus, D., and Crickmore, N. (2010). Bacillus thuringiensis: an impotent pathogen? Trends Microbiol. 18, 189-194. doi: 10.1016/j.tim.2010.02.006

Redondo-Nieto, M., Barret, M., Morrissey, J., Germaine, K., MartínezGranero, F., Barahona, E., et al. (2013). Genome sequence reveals that Pseudomonas fluorescens F113 possesses a large and diverse array of systems for rhizosphere function and host interaction. BMC Genomics 14:54. doi: 10.1186/14712164-14-54

Rochat, L., Péchy-Tarr, M., Baehler, E., Maurhofer, M., and Keel, C. (2010). Combination of fluorescent reporters for simultaneous monitoring of root colonization and antifungal gene expression by a biocontrol pseudomonad on cereals with flow cytometry. Mol. Plant Microbe Interact. 23, 949-961. doi: 10.1094/MPMI-237-0949

Ruffner, B. (2013). Insecticidal Activity in Plant-Beneficial Pseudomonads: Molecular Basis and Ecological Relevance. Ph.D. thesis No. 21005, ETH Zurich, Zurich.

Ruffner, B., Péchy-Tarr, M., Keel, C., and Maurhofer, M. (2009). Occurrence and molecular diversity of the Fit insect toxin locus in plant-beneficial pseudomonads. IOBC/WPRS Bull. 45, 251-254.

Ruffner, B., Péchy-Tarr, M., Ryffel, F., Hoegger, P., Obrist, C., Rindlisbacher, A., et al. (2013). Oral insecticidal activity of plant-associated pseudomonads. Environ. Microbiol. 15, 751-763. doi: 10.1111/j.14622920.2012.02884.X

Saitou, K., Furuhata, K., Kawakami, Y., and Fukuyama, M. (2009). Isolation of Pseudomonas aeruginosa from cockroaches captured in hospitals in 
Japan, and their antibiotic susceptibility. Biocontrol Sci. 14, 155-159. doi: 10.4265/bio.14.155

Sanahuja, G., Banakar, R., Twyman, R. M., Capell, T., and Christou, P. (2011). Bacillus thuringiensis: a century of research, development and commercial applications. Plant Biotechnol. J. 9, 283-300. doi: 10.1111/j.1467-7652.2011.00595.x

Shen, X., Hu, H., Peng, H., Wang, W., and Zhang, X. (2013). Comparative genomic analysis of four representative plant growth-promoting rhizobacteria in Pseudomonas. BMC Genomics 14:271. doi: 10.1186/14712164-14-271

Sibley, C. D., Duan, K., Fischer, C., Parkins, M. D., Storey, D. G., Rabin, H. R., etal. (2008). Discerning the complexity of community interactions using a Drosophila model of polymicrobial infections. PLoS Pathog. 4:e1000184. doi: 10.1371/journal.ppat.1000184

Silby, M. W., Winstanley, C., Godfrey, S. A. C., Levy, S. B., and Jackson, R. W. (2011). Pseudomonas genomes: diverse and adaptable. FEMS Microbiol. Rev. 35, 652-680. doi: 10.1111/j.1574-6976.2011.00269.x

Snyder, W. E., Tonkyn, D. W., and Kluepfel, D. A. (1998). Insect-mediated dispersal of the rhizobacterium Pseudomonas chlororaphis. Phytopathology 88, 12481254. doi: 10.1094/PHYTO.1998.88. 12.1248

Spinner, J. L., Jarrett, C. O., LaRock, D. L., Miller, S. I., Collins, C. M., and Hinnebusch, B. J. (2012). Yersinia pestis insecticidal-like toxin complex (Tc) family proteins: characterization of expression, subcellular localization, and potential role in infection of the flea vector. BMC Microbiol. 12:296. doi: 10.1186/14712180-12-296

Stavrinides, J., McCloskey, J. K., and Ochman, H. (2009). Pea aphid as both host and vector for the phytopathogenic bacterium Pseudomonas syringae. Appl. Environ. Microbiol. 75, 2230-2235. doi: 10.1128/AEM.02860-08

Stephens, J. M. (1958). Occurrence of Pseudomonas aeruginosa (Schroeter) Migula in haemolymph of grasshoppers after infection by feeding. Can. J. Microbiol. 4, 191-193. doi: 10.1139/m58-019

Tang, X., Freitak, D., Vogel, H., Ping, L., Shao, Y., Cordero, E. A., et al. (2012). Complexity and variability of gut commensal microbiota in polyphagous lepidopteran larvae. PLOS ONE 7:e36978. doi: 10.1371/journal.pone. 0036978

Tao, H. P., Shen, Z. Y., Zhu, F., Xu, X. F., Tang, X. D., and $\mathrm{Xu}, \mathrm{L}$. (2011). Isolation and identification of a pathogen of silkworm Bombyx mori. Curr. Microbiol. 62, 876-883. doi: 10.1007/s00284-010-9796-x

Thanwisai, A., Tandhavanant, S., Saiprom, N., Waterfield, N. R. Ke Long, P., Bode, H. B., et al. (2012). Diversity of Xenorhabdus and Photorhabdus spp. and their symbiotic entomopathogenic nematodes from Thailand. PLoS ONE 7:e43835. doi: 10.1371/journal.pone. 0043835

Toepfer, S., Kurtz, B., and Kuhlmann, U. (2010). Influence of soil on the efficacy of entomopathogenic nematodes in reducing Diabrotica virgifera virgifera in maize. J. Pest Sci. 83, 257-264. doi: 10.1007/s10340-0100293-6

Trippe, K., McPhail, K., Armstrong, D., Azevedo, M., and Banowetz, G. (2013). Pseudomonas fluorescens SBW25 produces furanomycin, a non-proteinogenic amino acid with selective antimicrobial properties. BMC Microbiol. 13:111. doi: 10.1186/ 1471-2180-13-111

Vachon, V., Laprade, R., and Schwartz, J. L. (2012). Current models of the mode of action of Bacillus thuringiensis insecticidal crystal proteins: a critical review. J. Invertebr. Pathol. 111, 1-12. doi: 10.1016/j.jip.2012. 05.001

Vallet-Gely, I., Lemaitre, B., and Boccard, F. (2008). Bacterial strategies to overcome insect defences. Nat Rev. Microbiol. 6, 302-313. doi: 10.1038/nrmicro1870

Vallet-Gely, I., Novikov, A., Augusto, L., Liehl, P., Bolbach, G., Péchy-Tarr, M., etal. (2010a). Association of hemolytic activity of Pseudomonas entomophila, a versatile soil bacterium, with cyclic lipopeptide production. Appl. Environ. Microbiol. 76, 910-921. doi: 10.1128/AEM. 02112-09

Vallet-Gely, I., Opota, O., Boniface, A., Novikov, A., and Lemaitre, B. (2010b). A secondary metabolite acting as a signalling molecule controls Pseudomonas entomophila virulence. Cell. Microbiol. 12, 16661679. doi: 10.1111/j.1462-5822.2010. 01501.x

van de Mortel, J. E., de Vos, R. C. H., Dekkers, E., Pineda, A., Guillod, L., Bouwmeester, K., et al. (2012). Metabolic and transcriptomic changes induced in Arabidopsis by the rhizobacterium Pseudomonas fluorescens SS101. Plant Physiol.
160, 2173-2188. doi: 10.1104/pp 112.207324

van den Bosch, R., and Stern, V. M. (1962). The integration of chemical and biological control of arthropod pests. Annu. Rev. Entomol. 7, 367386. doi: 10.1146/annurev.en.07. 010162.002055

Van der Ent, S., Verhagen, B. W., Van Doorn, R., Bakker, D., Verlaan, M. G., Pel, M. J., et al. (2008). MYB72 is required in early signaling steps of rhizobacteria-induced systemic resistance in Arabidopsis. Plant Physiol. 146, 1293-1304. doi: 10.1104/pp.107. 113829

Viggor, S., Juhanson, J., Joesaar, M., Mitt, J., Truu, J., Vedler, E. et al. (2013). Dynamic changes in the structure of microbial communities in Baltic Sea coastal seawater microcosms modified by crude oil, shale oil or diesel fuel. Microbiol. Res. 168, 415-427. doi: 10.1016/j.micres.2013.02.006

Vigneux, F., Zumbihl, R., Jubelin, G., Ribeiro, C., Poncet, J., Baghdiguian, S., et al. (2007). The $x a x A B$ genes encoding a new apoptotic toxin from the insect pathogen Xenorhabdus nematophila are present in plant and human pathogens. $J$. Biol. Chem. 282, 9571-9580. doi: 10.1074/jbc.M604301200

Vodovar, N., Vallenet, D., Cruveiller, S., Rouy, Z., Barbe, V., Acosta, C., et al. (2006). Complete genome sequence of the entomopathogenic and metabolically versatile soil bacterium Pseudomonas entomophila. Nat. Biotechnol. 24, 673-679. doi: $10.1038 /$ nbt1212

Vodovar, N., Vinals, M., Liehl, P., Basset, A., Degrouard, J., Spellman, P., et al. (2005). Drosophila host defense after oral infection by an entomopathogenic Pseudomonas species. Proc. Natl. Acad. Sci. U.S.A. 102, 11414-11419. doi: 10.1073/pnas. 0502240102

Vogt, S. L., Green, C., Stevens, K. M., Day, B., Erickson, D. L., Woods, D. E., etal. (2011). The stringent response is essential for $\mathrm{Pseu}$ domonas aeruginosa virulence in the rat lung agar bead and Drosophila melanogaster feeding models of infection. Infect. Immun. 79, 4094-4104. doi: 10.1128/IAI.00193-11

Walsh, U. F., Morrissey, J. P., and O'Gara, F. (2001). Pseudomonas for biocontrol of phytopathogens: from functional genomics to commercial exploitation. Curr. Opin. Biotechnol. 12, 289-295. doi: 10.1016/S09581669(00)00212-3

Watanabe, K., Hara, W., and Sato, M. (1998). Evidence for growth of strains of the plant epiphytic bacterium Erwinia herbicola and transconjugation among the bacterial strains in guts of the silkworm Bombyx mori. J. Invertebr. Pathol. 72, 104-111 doi: 10.1006/jipa.1998.4764

Waterfield, N. R., Bowen, D. J., Fetherston, J. D., Perry, R. D., and ffrench-Constant, R. H. (2001). The tc genes of Photorhabdus: a growing family. Trends Microbiol. 9, 185-191. doi: 10.1016/S0966-842X (01)01978-3

Waterfield, N. R., Ciche, T., and Clarke, D. (2009). Photorhabdus and a host of hosts. Annu. Rev. Microbiol. 63, 557-574. doi: 10.1146/annurev. micro.091208.073507

Weller, D. M. (2007). Pseudomonas biocontrol agents of soilborne pathogens: looking back over 30 years. Phytopathology 97, 250-256. doi: 10.1094/PHYTO-97-2-0250

Weller, D. M., Mavrodi, D. V., van Pelt, J. A., Pieterse, C. M., van Loon, L. C., and Bakker, P. A. (2012). Induced systemic resistance in Arabidopsis thaliana against Pseudomonas syringae pv. tomato by 2,4-diacetylphloroglucinolproducing Pseudomonas fluorescens. Phytopathology 102, 403-412. doi: 10.1094/PHYTO-08-11-0222

Weller, D. M., Raaijmakers, J. M., Gardener, B. B. M., and Thomashow, L. S. (2002). Microbial populations responsible for specific soil suppressiveness to plant pathogens. Annu. Rev. Phytopathol. 40, 309348. doi: 10.1146/annurev.phyto.40. 030402.110010

Wu, X., Monchy, S., Taghavi, S., Zhu, W., and Ramos, J. (2010). Comparative genomics and functional analysis of niche-specific adaptation in Pseudomonas putida. FEMS Microbiol. Rev. 35, 299323. doi: 10.1111/j.1574-6976.2010. 00249.x

Youard, Z. A., Wenner, N., and Reimmann, C. (2011). Iron acquisition with the natural siderophore enantiomers pyochelin and enantiopyochelin in Pseudomonas species. Biometals 24, 513-522. doi: 10.1007/s10534-010-9399-9

Zamioudis, C., and Pieterse, C. M. (2012). Modulation of host immunity by beneficial microbes. Mol. Plant Microbe Interact. 25, 139-150. doi: 10.1094/MPMI-06-11-0179

Conflict of Interest Statement: The authors declare that the research was conducted in the absence of any commercial or financial relationships that could be construed as a potential conflict of interest. 
Received: 03 May 2013; accepted: 12 July 2013; published online: 31 July

2013.

Citation: Kupferschmied P, Maurhofer M and Keel C (2013) Promise for plant pest control: root-associated pseudomonads with insecticidal activities. Front. Plant Sci. 4:287. doi: 10.3389/fpls.2013. 00287

This article was submitted to Frontiers in Plant-Microbe Interaction, a specialty of Frontiers in Plant Science.
Copyright: (c) 2013 Kupferschmied, Maurhofer and Keel. This is an open-acces article distributed under the terms of the Creative Commons Attribution License (CC BY). The use, distribution or reproduction in other forums is permitted, provided the original author(s) or licensor are credited and that the original publication in this journal is cited, in accordance with accepted academic practice. No use, distribution or reproduction is permitted which does not comply with these terms. 